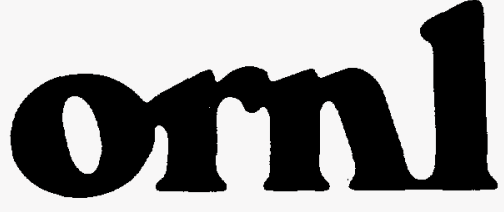

OAK RIDGE NATIONAL LABORATORY

\section{MARTIN MARIETTA}

\title{
RECEIVED
}

MAR 041996

OSTI

Preliminary Probabilistic Design Basis Accident Evaluation of the Cold Source Facilities of the Advanced Neutron Source

R. M. Harrington

C. T. Ramsey

August 1995

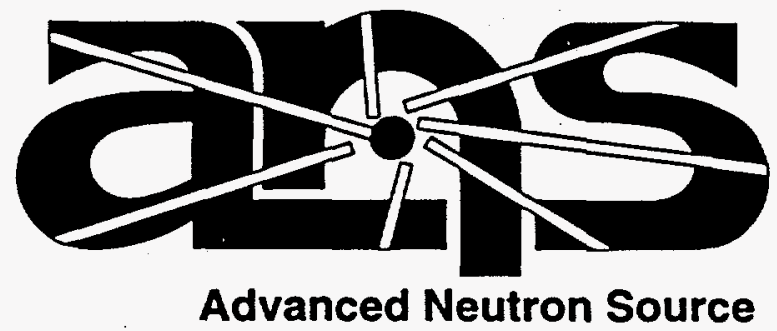


This report has been reproduced directly from the best available copy.

Available to DOE and DOE contractors from the Office of Scientific and Technical Information, P.O. Box 62, Oak Ridge, TN 37831; prices available from (615) 576-8401, FTS 626-8401.

Available to the public from the National Technical Information Service, U.S. Department of Commerce, 5285 Port Royal Rd., Springfield, VA 22161.

This report was prepared as an account of work sponsored by an agency of the United States Government. Neither the United States Government nor any agency thereot, nor any of their employees, makes any warranty. express or implied, or assumes any legal liability or responsibility for the accuracy, completeness, or usefuiness of any information, apparatus, product, or process disclosed. or represents that its use would not intringe privately owned rights. Reference herein to any specific commercial product, process, or service by trade name, trademark, manufacturer, or otherwise, does not necessarily consttute or imply its endorsement, recommendation, or favoring by the United States Government or any agency thereof. The views and opinions of authors expressed herein do not necessarily state or reflect those of the United States Government or any agency thereot. 


\title{
PRELIMINARY PROBABILISTIC DESIGN BASIS ACCIDENT EVALUATION OF THE COLD SOURCE FACILITIES OF THE ADVANCED NEUTRON SOURCE
}

\author{
R. M. Harrington \\ C. T. Ramsey
}

Date published: August 1995

\author{
Prepared by \\ OAK RIDGE NATIONAL LABORATORY \\ Oak Ridge, Tennessee 37831-8218 \\ managed by \\ LOCKHEED MARTIN ENERGY SYSTEMS, INC. \\ for the \\ U.S. DEPARTMENT OF ENERGY \\ under contract DE-AC05-84OR21400
}




\section{CONTENTS}

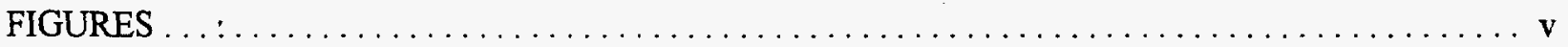

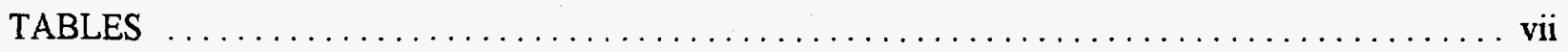

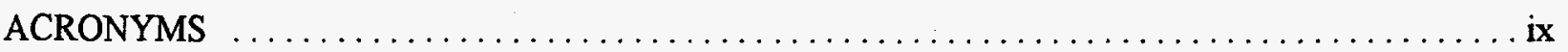

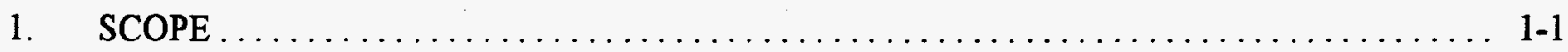

2. COLD SOURCE DESIGN AND SAFETY CHARACTERISTICS $\ldots \ldots \ldots \ldots \ldots \ldots \ldots \ldots . \ldots 2-1$

2.1 SAFETY PHILOSOPHY IN COLD SOURCE DESIGN $\ldots \ldots \ldots \ldots \ldots \ldots \ldots \ldots \ldots$ 2-1

2.2 COLD SOURCE SYSTEM PURPOSE AND OPERATING REQUIREMENTS . . . . . 2-2

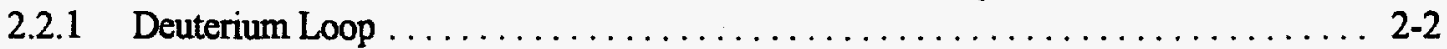

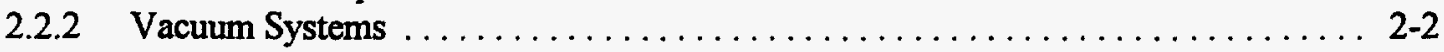

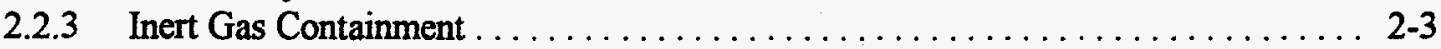

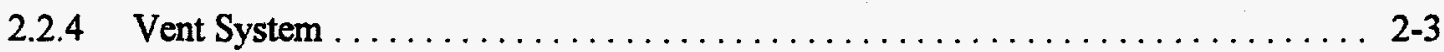

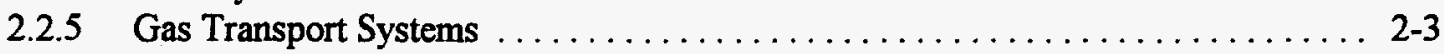

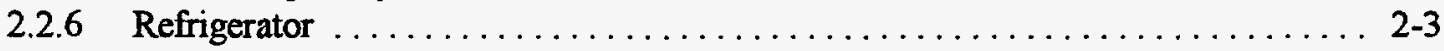

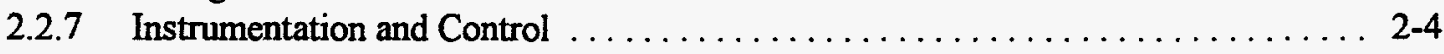

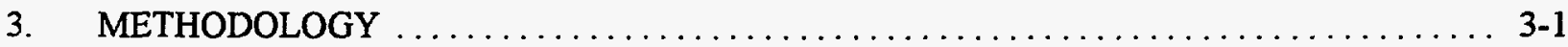

4. INPUT CONSIDERED FOR ACCIDENT EVALUATION $\ldots \ldots \ldots \ldots \ldots \ldots \ldots \ldots \ldots .4$

4.1 WORLD EXPERIENCE WITH REACTOR-BASED $\mathrm{H}_{2}-\mathrm{OR} \mathrm{D}_{2}$-BASED

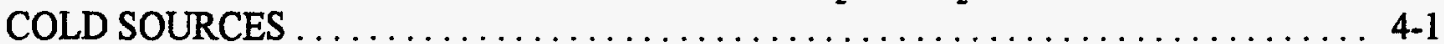

4.2 CONVERSATIONS WITH SYSTEM DESIGNERS $\ldots \ldots \ldots \ldots \ldots \ldots \ldots \ldots \ldots .4$

4.3 DATA SOURCES $\ldots \ldots \ldots \ldots \ldots \ldots \ldots \ldots \ldots \ldots \ldots \ldots \ldots \ldots \ldots \ldots \ldots$

4.3.1 Generic Failure Data References ........................... 4-4

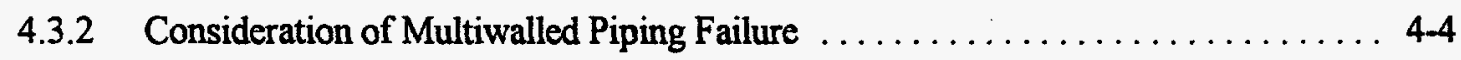

5. PRELIMINARY MODELING AND SELECTION OF INITIATING EVENTS $\ldots \ldots \ldots \ldots \ldots$

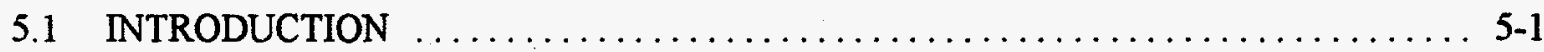

5.2 MASTER LOGIC DIAGRAM AND INITIATING EVENT CATEGORIZATION . . . . . 5-1

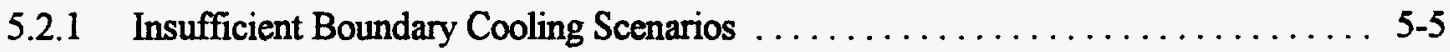

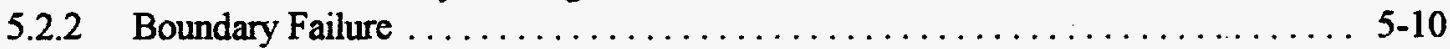

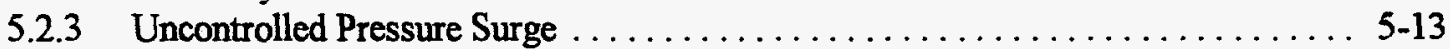

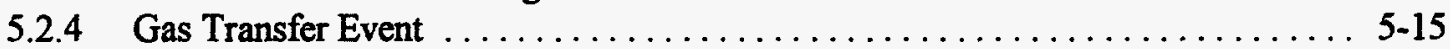

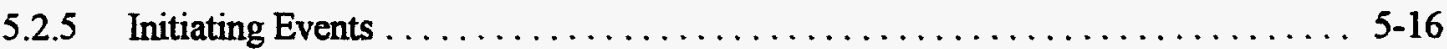

6. PRELIMINARY LIST OF DESIGN BASIS EVENTS FOR THE ANS COLD SOURCES . . . . . 6-1

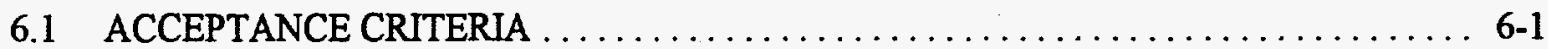

6.2 SELECTING A COMPLETE LIST OF DBES $\ldots \ldots \ldots \ldots \ldots \ldots \ldots \ldots \ldots \ldots \ldots \ldots$

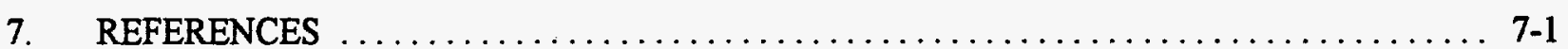




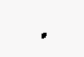

.

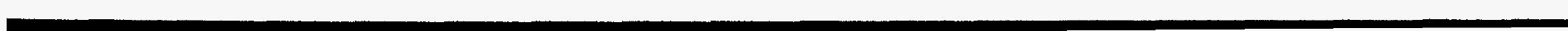




\section{FIGURES}

Figure

$\underline{\text { Page }}$

1.1. Steps in the selection of design basis accidents with the aid of PRA. $\ldots \ldots \ldots \ldots \ldots \ldots \ldots \ldots$

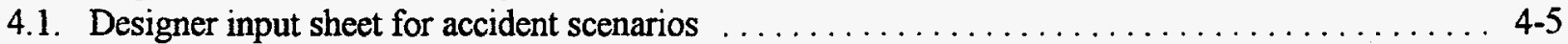

4.2. Cut-away of the cold source beam thimble and internals showing the $\mathrm{D}_{2}$ moderator vessel (left) and concentric inlet/outlet piping. The half-elipse object at right is a neutron window . . . 4 4-6

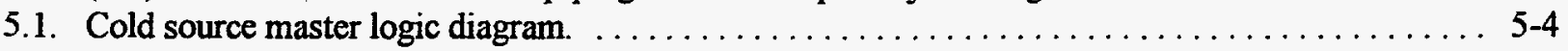

5.2. Loss of boundary cooling event sequence diagram. $\ldots \ldots \ldots \ldots \ldots \ldots \ldots \ldots \ldots \ldots \ldots$

5.3. Simplified cold source heat load schematic. $\ldots \ldots \ldots \ldots \ldots \ldots \ldots \ldots \ldots \ldots \ldots \ldots \ldots \ldots$

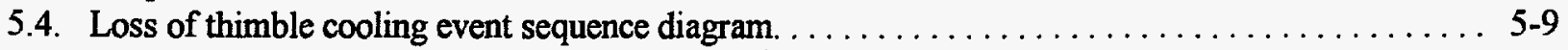

5.5. Breach of moderator vessel/circulator piping event sequence diagram $\ldots \ldots \ldots \ldots \ldots \ldots \ldots$ 5-12

5.6. Cross section of joint between two lengths of multijacketed piping $\ldots \ldots \ldots \ldots \ldots \ldots \ldots \ldots$ 5-14

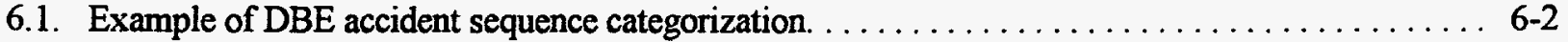




\section{TABLES}

Table

Page

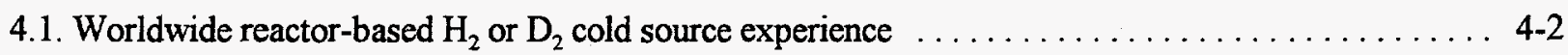

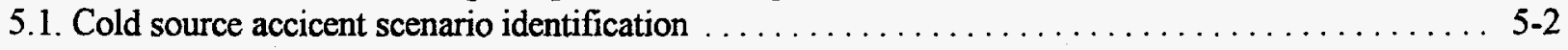

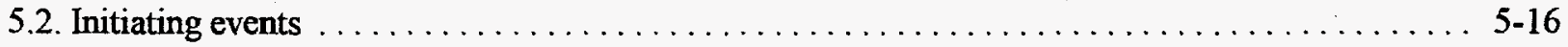

6.1. Preliminary acceptance criteria for ANS design basis event analysis $\ldots \ldots \ldots \ldots \ldots \ldots \ldots \ldots 6-2$ 
. 


\section{ACRONYMS}

ANS

ASME

BDB

BNL

CPBT

$\mathrm{D}_{2}$

$\mathrm{D}_{2} \mathrm{O}$

DBE

ESD

FMEA

$\mathrm{GD}_{2}$

HFBR

IBC

$\mathrm{LD}_{2}$

$\mathrm{LH}_{2}$

LOSP

MLD

PRA

PDR
Advanced Neutron Source

American Society of Mechanical Engineers

beyond design basis

Brookhaven National Laboratory

core pressure boundary tube

deuterium

deuterium oxide

design basis event

event sequence diagram

failure modes and effects analysis

gaseous deuterium

High Flux Beam Reactor

insufficient boundary cooling

liquid deuterium

liquid hydrogen

loss of off-site power

master logic diagram

probabilistic risk assessment

plant design requirements 


\author{
.
}




\section{SCOPE}

Consistent with established Advanced Neutron Source (ANS) project policy for the use of probabilistic risk assessment (PRA) in design, a task has been established to use PRA techniques to help guide the design and safety analysis of the ANS cold sources. The work discussed in this report is the first formal output of the cold source PRA task. The major output at this stage is a list of design basis accidents, categorized into approximate frequency categories. This output is expected to focus attention on continued design work to define and optimize the design such that design basis accidents are better defined and have acceptable outcomes. Categorizing the design basis events (DBEs) into frequency categories should prove helpful because it will allow appropriate acceptance criteria to be applied. Because the design of the cold source is still proceeding, it is beyond the scope of this task to produce detailed event probability calculations or even, in some cases, detailed event sequence definitions. That work would take place as a logically planned follow-on task, to be completed as the design matures.

Figure 1.1 illustrates the steps that would typically be followed in selecting design basis accidents with the help of PRA. Only those steps located above the dashed line on Fig. 1.1 are included in the scope of the present task. (Only an informal top-level failure modes and effects analysis was done.) With ANS project closeout expected in the near future, the scope of this task has been abbreviated somewhat beyond the state of available design information on the ANS cold sources, or what could be achieved in a reasonable time. This change was necessary to ensure completion before the closeout and because the indepth analytical support necessary to define fully some of the accidents has already been curtailed.

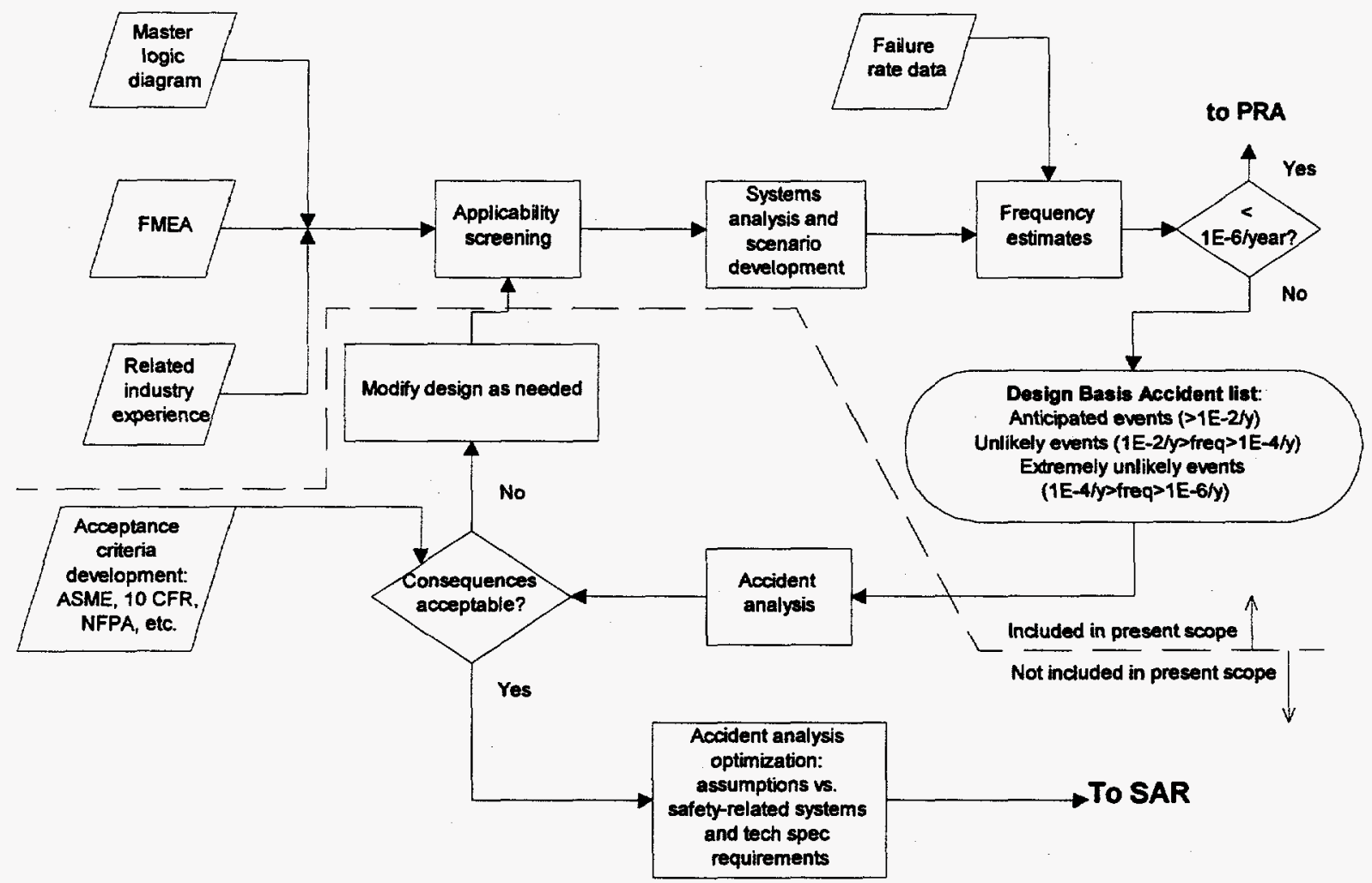

Fig. 1.1. Steps in the selection of design basis accidents with the aid of PRA. 



\section{COLD SOURCE DESIGN AND SAFETY CHARACTERISTICS}

In deterministic safety analyses, some type of single-failure criteria are usually applied to safety systems designed to mitigate the consequences of an accident. By assuming this failure has occurred, the value of redundant and diverse safety features is often ignored for the sake of conservatism. The probabilistic methodology is like the deterministic method in that it acknowledges that the possibility of failure of these systems exists but also considers the likelihood of that failure in evaluating the stature of an accident sequence.

The ANS cold source and supporting systems are to be designed with emphasis on safety and operability. By designing the cold source in this manner, both the frequency of an abnormal event and the likelihood of failing to cope with that event are decreased greatly. This section highlights the design features of the cold source(s) with regard to accident prevention and mitigation.

\subsection{SAFETY PHILOSOPHY IN COLD SOURCE DESIGN}

Although the cold sources are close to the reactor core, they are outside of the reflector vessel boundary and therefore are not considered part of the reactor system for safety considerations. The cold source (outer) thimbles that are in the reflector vessel are ASME III, Class 2 pressure boundaries. Supplemental Design Criteria 73 of the ANS Plant Design Requirements" (PDR) states that each experiment system "shall be designed to ensure an extremely low probability $(<10-6 / y r)$ that any event originating within or principally determined by that system would lead to loss of integrity of either the reactor fuel or the reactor containment." Therefore, the cold source system safety goals were established to preclude any of the following events: (1) loss of reactor containment, (2) damage to the reactor assembly, (3) loss of reactor shutdown capability, or (4) damage to any other reactor safety system. To meet these very stringent risk limitation objectives it is necessary to ensure that no single credible boundary failure could result in any of the following occurrences: (1) contact between liquid deuterium $\left(\mathrm{LD}_{2}\right)$ and deuterium oxide $\left(\mathrm{D}_{2} \mathrm{O}\right),(2)$ pressure in the deuterium loop rising above its maximum design point, and (3) any kind of energetic reaction.

To maintain personnel safety in the vicinity of any part of the cold source system, no design basis event, compounded by a single credible failure, shall allow deuterium to be released into the containment building or to come into contact with air.

In light of these goals, there are three principles considered in the safety analysis of the cold sources:

1. Limitation of pressure in the systems. This is addressed by operating the deuterium in a closed loop in conjunction with a $30 \mathrm{~m}^{3}$ expansion vessel. Pressure is controlled by transferring deuterium inventory between the expansion vessel (which remains at ambient temperature) and the $\mathrm{LD}_{2}$ circulating loop as dictated by system conditions. The deuterium loop remains at nominally the same pressure while the expansion vessel pressure falls to $0.1 \mathrm{MPa}$. When the cold source is allowed to heat back up to ambient temperatures, the system pressure, including that of the expansion vessel, is $0.4 \mathrm{MPa}$. A relief valve/rupture disc set limits the deuterium loop pressure to a maximum of $0.6 \mathrm{Mpa}$ by venting to the 60 $\mathrm{m}^{3}$ vent vessel. The vacuum systems and the inert gas envelopes are also protected against positive pressure by rupture discs. All rupture discs are connected to the vent system, which can contain a full inventory of gas at a maximum pressure of $0.12 \mathrm{MPa}$. 
2. Prevention of an explosion. This is addressed by maintaining double containment between deuterium and air. Components vulnerable to leakage are located in a safe-room that is monitored constantly for deuterium gas. The room has a fully independent closed circuit cleanup system, incorporating a catalyst, to convert any leaked gas to heavy water for removal to the detritiation plant.

3. Tritium control. The previous measures will adequately control the frequency of tritium release events. Additionally, the tritium content in each cold source will be limited to about $1.5 \mathrm{~g}$ by regular deuterium inventory changes about once every two years. This controls and/or limits the radiological risks associated with potential tritium release events.

\subsection{COLD SOURCE SYSTEM PURPOSE AND OPERATING REQUIREMENTS}

The overall function of the cold sources is to provide a flux of very low energy neutrons $(<10 \mathrm{meV})$ at an effective temperature of $40 \mathrm{~K}$ or less to the cold and very cold neutron transport systems. The overall operational requirements for the cold sources are as follows:

1. Before the reactor is started, each cold source loop will be filled with liquid deuterium cooled to $20 \mathrm{~K}$ at the heat exchanger. This operation is designed to take about $24 \mathrm{~h}$.

2. At all reactor power levels and operational conditions, the liquid deuterium must remain subcooled throughout the loop. This requires control of both pressure and temperature. The liquid will be maintained at $20 \mathrm{~K}$ at the heat exchanger exit and at a pressure of $0.25 \mathrm{MPa}$ at a point just upstream of the circulator.

3. At the end of each fuel cycle, each moderator is required to be annealed by raising its temperature to $100^{\circ} \mathrm{C}$. There is no requirement for this temperature to be sustained, but both cold source systems must be operational within $4 \mathrm{~d}$ (i.e., within the refueling time window).

\subsubsection{Deuterium Loop}

Each cold source system will require an inventory of $19 \mathrm{~kg}$ of $\mathrm{D}_{2}$ that remains resident in the loop until removed or until the vent system is activated. A $30-\mathrm{m}^{3}$ expansion vessel comprises a part of the loop, which will allow the pressure to be held at $0.4 \mathrm{MPa}$ with the loop at ambient temperature. During normal operation, the pressure in the expansion vessel will be reduced to $0.1 \mathrm{MPa}$, but the liquid pressure at the inlet point of the circulator will be controlled at $0.25 \mathrm{MPa}$. A mass flow rate in the circulating loop of $1 \mathrm{~kg} / \mathrm{s}$ will be maintained during normal operation. Components in the loops will have redundant seals to ensure that a leak in the liquid deuterium circulating loop(s) does not occur. A redundant circulator, isolated by cryogenic valves, will be installed in the loop. It is a requirement to be able to replace a redundant circulator while the loop is operating. Both circulators will be bypassed during the cooldown and liquefaction phases to allow the system to be filled using natural convection. Once the loop is full, one circulator will be brought on line to subcool the liquid to $20 \mathrm{~K}$ (at the point of leaving the heat exchanger).

\subsubsection{Vacuum Systems}

The entire circulating cold loop will be vacuum insulated; however, the vacuum envelope will be split into two sectors, one for the thimble assembly and the other for the transfer lines, pumping module, and the heat exchanger. A vacuum pressure of about $0.0001 \mathrm{~Pa}$ is anticipated in each section. Both systems will be provided with gas analyzers, to give early indication of leaks, and will be independently protected against 
positive pressure in the event of a system failure. Rupture discs set at $0.4 \mathrm{MPa}$ will discharge into the main cold source vent system. Pumping stations will be composed of turbo and backing pumps, gas analyzers, and isolation valves. Each station will be duplicated by a redundant unit.

\subsubsection{Inert Gas Containment}

The entire deuterium containing loop, including those parts that are vacuum insulated, shall be within an inert gas blanket. The blanket gas containment will be split into two sectors, one for the thimble assembly and the other for the remainder of the loop. Vacuum pump stations will be designed with gas blanket containment that can be coupled or uncoupled to the main blanket system while preserving its integrity at all times. Both gas blanket systems will be protected against pressures higher than $0.4 \mathrm{MPa}$ by rupture discs that will discharge into the main vent system.

\subsubsection{Vent System}

Points of ventilation in the loop, including rupture discs and relief valves, discharge into a $60-\mathrm{m}^{3}$ vent vessel that will normally be held under vacuum. The vessel will be double walled with a separate vacuum in the interspace that will be pumped continuously. Expansion to a $60-\mathrm{m}^{3}$ volume would be sufficient to contain the entire deuterium inventory at ambient temperature at a pressure of $0.12 \mathrm{MPa}$.

A safe-room will contain equipment most vulnerable to leaks. Electrical equipment within the room shall be specified as intrinsically safe or inert gas blanketed. The main reactor building ventilation system will normally provide service to the safe-room. If deuterium gas is detected in the safe-room, ventilation in the safe-room will be isolated from the plant system, and a closed-loop cleanup system, incorporating a catalytic converter, will actuate to remove the deuterium by converting it to heavy water. The heavy water may then be removed to the detritiation plant in a portable molecular sieve.

\subsubsection{Gas Transport Systems}

When an inventory change is required, all the deuterium will be pumped into the $60-\mathrm{m}^{3}$ vent vessel at a pressure of $0.2 \mathrm{MPa}$, allowing the deuterium loop to be filled with inert gas. This represents a different function for the vent vessel than that described in Sect. 2.2.4; consequently, different pressures are given. Portable hydride units will then be used to remove the deuterium from the vent vessel, leaving it under vacuum. Replacement will be a reversal of this procedure. The hydride units will be used for all transportation of deuterium; and, in addition to being interchangeable, they will be designed to maintain the double containment philosophy during connection and disconnection. Service connections will be fitted to provide heating for gas discharge or cooling for gas intake.

\subsubsection{Refrigerator}

The cold source refrigerators that supply cryogenic helium to keep the $\mathrm{D}_{2}$ subcooled during reactor operation shall be independent of each other and are described in ref. 2. Refrigeration (helium temperature) control shall be provided by electrical heaters that will operate in response to one of three temperature sensors located (a) in the deuterium loop "cold" leg, (b) in the main heat exchanger, and (c) in the helium loop "hot" leg. 


\subsubsection{Instrumentation and Control}

Instrumentation systems will control the temperature and pressure of the cold circulating loops and provide additional indication at other points of the circuit. Additional important information, such as vacuum and blanket gas pressures, will also be measured. Temperature control of the liquid deuterium will be in response to one of three alternative sensors, depending on the current mode of operation. The instrumentation and control system will also provide the protection required to meet the overall safety requirements by interlocking and interconnecting parameter functions during the respective modes of operation. 


\section{METHODOLOGY}

Selecting design basis accident scenarios first requires compiling a list of many potential accidents, which can be approached in several ways. Failure modes and effects (FMEA) analysis, the master logic diagram (MLD), and direct interviews with the system designers were all used to compile a preliminary categorization of design basis accident scenarios for the ANS cold sources. The FMEA, in its most rigorous application, moves component by component through a system assessing the impact that the failure of each component has on system availability, operation, and safety. In this way, accident scenarios originating as a result of inter- and inner-system failures are identified for further consideration. The degree of rigor is, in many cases, tied to the development of the design. In the case of the ANS cold sources, the FMEA included most active components and some instrumentation. The FMEA is discussed in Sect. 5.

The MLD approach, used in many PRAs to help categorize accidents, uses a top-down approach to descriminate between accident types. Beginning with the undesired consequence (e.g., release of gaseous $\mathrm{D}_{2}$ into the containment), the MLD branches out into the accident scenario categories that could terminate in that consequence. Below the scenario categories, the entries become more function and system specific. The lowest level in the MLD represents the least general event presentable in this format, forming the initiating event subcategories. Fault trees and event trees are then used to assess on a system-by-system basis how functions could become unavailable or components fail in such a way as to result in the MLD accident scenario.

The construction of the MLD is the extent of analysis performed on the ANS cold sources (Sect. 5). A detailed availability study was performed on the cold sources and supporting systems (refrigeration and vacuum) to pinpoint areas in the design that could critically impact cold source availability and also plant availability because of the safety set point for cold source operation. The availability study used fault tree analysis to model the performance of system components during normal operation. In addition to the estimate of cold source availability and frequency of unavailability, further knowledge of the relationship that exists between each component and system operation was gained. This knowledge was applied, to a certain extent, in estimating initiating event frequencies later in this report.

Interviewing the ANS cold source system designers, although not always a viable option in every situation, proved to be very fruitful in both identifying concerns and potential scenarios as well as confirming the findings of the FMEA and MLD methods. These interviews were also instrumental in the safety analysts' understanding of the design and intended operation of the cold sources, particularly in the application of multiwalled piping, vacuum separation, and pressure relief. The designers were able to identify their uncertainty surrounding specific failure modes as well as explain what mitigating features already exist to combat the consequences of postulated accidents. Further discussion and presentation of the designers' input follows in Sects. 4 and 5. 


\section{INPUT CONSIDERED FOR ACCIDENT EVALUATION}

\subsection{WORLD EXPERIENCE WITH REACTOR-BASED $\mathrm{H}_{2}-\mathrm{OR}_{2}$-BASED COLD SOURCES}

Cold sources were first used extensively in the United Kingdom, at Harwell Laboratory. The experience and capabilities proven there spawned a whole generation of cold sources around the world. As reported in the 1990 Cold Source Workshop ${ }^{2}$ at Los Alamos, more than 100 years of experience with hydrogen-based cold sources has been amassed since the 1960s. Most of this experience appears to have been good, from the scientific, safety, and operational viewpoints. Table 4.1. summarizes relevant world experience with reactor cold sources. Only one event of potential safety significance was mentioned at the 1990 workshop-the rupture of the moderator vessel at the High Flux Beam Reactor (HFBR) at Brookhaven National Laboratory (BNL). As explained subsequently, the BNL cold source employs a unique cold source design.

There are three different types of $\mathrm{LH}_{2}$ cold source cooling systems: (1) saturated $\mathrm{LH}_{2}$ systems with vapor transport to a helium-cooled condenser (DIDO, FR2, HFR/LL, Orphee, FRJ-2, KUR, and NIST), (2) supercritical $\mathrm{H}_{2}$ systems with pumped flow between the reactor and a helium-cooled heat exchanger (Riso, FRG-1, and BER-2), and (3) one noncirculating moderator vessel cooled by externally attached cold helium lines (BNL). The design of these systems is dictated by the gamma/neutron heating rate at the desired irradiation location, the size of the space in which the cold source must fit, and other constraints. Inventory control of the circulating systems (i.e., all but BNL) is maintained by arranging for highly reliable transport of $\mathrm{H}_{2}$ between a high-integrity expansion vessel (volume on the order of $1 \mathrm{~m}^{3}$ ) and the cryogenic moderator vessel (volume on the order of $1 \mathrm{~L}$ ). The initially gaseous $\mathrm{H}_{2}$ is drawn from the expansion vessel into the moderator vessel when $\mathrm{H}_{2}$ condensation begins as cryogenic temperatures are reached in the helium-cooled condenser. After operation is complete and the helium refrigerator is turned off (generally, the reactor must also be shutdown), the $\mathrm{LH}_{2}$ in the moderator vessel vaporizes and returns to the expansion vessel. Typically, the expansion vessel is located outside the safety-significant part of the reactor. Inventory control for the noncirculating HFBR (BNL) cold source is based on disposing of the hydrogen charge by flushing with an inert gas after each operational period.

The subcooled $\mathrm{LH}_{2}$ forced circulation cooling system for the proposed ANS cold source differs from the existing world experience base for reactor-based hydrogen cold sources. The ANS cooling system shares the use of forced circulation with the Riso/Interatom design but differs in that the Riso design involves supercritical $\mathrm{H}_{2}$, whereas the ANS design uses subcooled $\mathrm{LD}_{2}$. This means that during operational upsets or accidents, the ANS design and analysis will have to consider the pressure, flow, and heat transfer dynamics associated with two-phase flow during some unlikely events. The Riso design does not have to be concerned with two-phase phenomena because there is only one phase in the supercritical region as long as pressure is maintained. The necessary pressure of 15 bar was not practical with ANS. Extensive analysis and testing will be required to show that the ANS cold sources can perform satisfactorily during off-nominal events involving two-phase conditions.

The basic safety philosophy for nearly all the cold sources comprise the following elements: (1) ensure very high purity $\mathrm{H}_{2}$ when new gas is charged; (2) maintain the $\mathrm{H}_{2}$ within a closed system that has dual and triple barriers to guard against escape of $\mathrm{H}_{2}$ or inleakage of contaminants such as oxygen; (3) include in the outermost barrier a monitored layer that could be an independent vacuum or inert gas; (4) notwithstanding the efforts to prevent $\mathrm{H}_{2}-\mathrm{O}_{2}$ combination, ensure that at least one of the boundaries has sufficient structural strength to prevent damage to the reactor in case of an internal explosion; (5) provide reactor shutdown to reduce heat loads on the cold source when cryogenic cooling has been lost; (6) select materials for resistance to hydrogen embrittlement; (7) place $\mathrm{H}_{2}$ bearing components, vessels, and lines in protected locations; and (8) ensure that the expansion vessel is of very conservative, high-integrity design and, preferrably, is located outside the immediate area of the reactor. 
Table 4.1. Worldwide reactor-based $\mathrm{H}_{2}$ or $\mathrm{D}_{2}$ cold source experience ${ }^{a}$

\begin{tabular}{|c|c|c|c|c|}
\hline \multirow{2}{*}{ Reactor } & \multirow{2}{*}{ Description } & \multirow{2}{*}{ Cold source } & \multicolumn{2}{|r|}{ Cold source experience } \\
\hline & & & $\begin{array}{l}\text { Duration } \\
\text { (years) }\end{array}$ & Quality \\
\hline $\begin{array}{l}\text { DIDO at Harwell, } \\
\text { U. K. (shut down in } \\
\text { 1990) }\end{array}$ & $\begin{array}{l}25-\mathrm{MW} \text { heavy } \\
\text { water cooled and } \\
\text { moderated }\end{array}$ & $\begin{array}{l}\text { Natural circulation, saturated } \mathrm{H}_{2} \text { loop with He- } \\
\text { cooled condenser. }\end{array}$ & $\sim 30$ & $\begin{array}{l}\text { Evidently quite good since this spawned the whole current generation } \\
\text { of world reactor cold sources (listed below). }\end{array}$ \\
\hline $\begin{array}{l}\text { FR-2 atKarisruhe } \\
\text { (shut down 1981) }\end{array}$ & $\begin{array}{l}\text { 44-MW tank } \\
\text { reactor }\end{array}$ & $\begin{array}{l}\text { Natural circulation, saturated } \mathrm{H}_{2} \text { loop with He- } \\
\text { cooled condenser. }\end{array}$ & $\sim 20$ & \\
\hline $\begin{array}{l}\text { HFR at ILL, } \\
\text { Grenoble, France }\end{array}$ & $\begin{array}{l}60-\mathrm{MW} \mathrm{D}_{2} \mathrm{O} \\
\text { cooled and } \\
\text { moderated }\end{array}$ & $\begin{array}{l}\text { "Vertical" cold source: saturated } D_{2} \text {, natural } \\
\text { circulation loop with He-cooled condenser. }\end{array}$ & 22 & $\begin{array}{l}\text { The CNS operation is closely connected with reactor operation. Since } \\
\text { there is no emergency cooling of the in-pile parts, reactor power has to } \\
\text { be reduced when the CNS cooling is inadquate; the reactor is shut } \\
\text { down (scram) when the refrigerator fails for more than } 1 \text { min. The } \\
\text { high mean time between failure of the refrigerator and backup } \\
\text { compressors reduces perturbations to less than } 1 \% \text { of reactor } \\
\text { operation time. }\end{array}$ \\
\hline $\begin{array}{l}\text { HFR at ILL, } \\
\text { Grenoble, France }\end{array}$ & $\begin{array}{l}60-\mathrm{MW} \mathrm{D}_{2} \mathrm{O} \\
\text { cooled and } \\
\text { moderated }\end{array}$ & $\begin{array}{l}\text { "Horizontal" cold source: saturated } D_{2} \text {, natural } \\
\text { circulation loop with He-cooled condenser. }\end{array}$ & 6 & \\
\hline $\begin{array}{l}\text { Orphee at Saclay } \\
\text { (CEN), France }\end{array}$ & $\begin{array}{l}\text { 14-MW light } \\
\text { water pool }\end{array}$ & $\begin{array}{l}\text { Natural circulation, saturated } \mathrm{H}_{2} \text { loop with } \mathrm{He} \text { - } \\
\text { cooled condenser. }\end{array}$ & & \\
\hline $\begin{array}{l}\text { DR-3 at Riso } \\
\text { National Laboratory, } \\
\text { Denmark }\end{array}$ & $\begin{array}{l}\text { 10-NW heavy } \\
\text { water moderated } \\
\text { Pluto-type } \\
\text { reactor. }\end{array}$ & $\begin{array}{l}\text { Circulator-driven supercritical hydrogen loop with } \\
\text { He-cooled heat exchanger (standby freon-cooled } \\
\text { heat exchanger loop provided). }\end{array}$ & 15 & $\begin{array}{l}\text { During } 15 \text { years of operation, cold neutrons have been available more } \\
\text { than } 95 \% \text { of the time. Shutdown of the cold neutron facility has } \\
\text { essentially always been caused by vacuum leaks or cryogenerator } \\
\text { problems. It has proven essential to have two cryogenerators to ensure } \\
\text { adequate availability. }\end{array}$ \\
\hline $\begin{array}{l}\text { FRG-1 (\&FRG-2 } \\
\text { ??) Germany }\end{array}$ & $\begin{array}{l}\text { FRG-1: 5-MW } \\
\text { FRG-2: } 15 \text { light } \\
\text { water pool type }\end{array}$ & $\begin{array}{l}\text { Design by Riso/Interatom consortium (very similar } \\
\text { to Riso design). }\end{array}$ & $\sim 6$ years & $\begin{array}{l}\text { Initial installation; many troubles with warm and cold } \mathrm{H}_{2} \text { and } \mathrm{He} \\
\text { leaks had to be solved; after commissioning, there was a 3-month } \\
\text { outage caused by leaking cryovalves at cold temperatures. Otherwise } \\
\text { satisfactory. }\end{array}$ \\
\hline $\begin{array}{l}\text { BER-2 at Hahn- } \\
\text { Meitner Institute in } \\
\text { Berlin, Germany }\end{array}$ & $\begin{array}{l}\text { 10-MW, light } \\
\text { water cooled and } \\
\text { moderated }\end{array}$ & $\begin{array}{l}\text { Design by Riso/Interatom consortium (very similar } \\
\text { to Riso design). }\end{array}$ & & \\
\hline $\begin{array}{l}\text { FRJ-2 at Julich, } \\
\text { Germany }\end{array}$ & $\begin{array}{l}15 \mathrm{MW} \text { up- } \\
\text { graded to } 23 \\
\text { MW. DIDO-type } \\
\text { reactor }\end{array}$ & $\begin{array}{l}\text { Natural circulation, saturated } \mathrm{H}_{2}\left(20 \%, \mathrm{D}_{2}\right. \\
\text { admixture since 1975) loop with He-cooled } \\
\text { condenser. }\end{array}$ & $\begin{array}{l}22 \text { (Original version } \\
1969-1987 . \text { New } \\
\text { version since } 1987 .\end{array}$ & Operation "successful." \\
\hline
\end{tabular}


Table 4.1 (continued)

\begin{tabular}{|c|c|c|c|c|}
\hline \multirow[b]{2}{*}{ Reactor } & \multirow{2}{*}{ Description } & \multirow{2}{*}{ Cold source } & \multicolumn{2}{|r|}{ Cold source experience } \\
\hline & & & $\begin{array}{l}\text { Duration } \\
\text { (years) }\end{array}$ & Quality \\
\hline $\begin{array}{l}\text { KUR RRI, Kyoto, } \\
\text { Japan }\end{array}$ & $\begin{array}{l}\text { 5-MW light } \\
\text { water tank- } \\
\text { type }\end{array}$ & $\begin{array}{l}\text { Natural circulation, saturated } 10 \% \mathrm{H}_{2} \text { and } \\
90 \% \mathrm{D}_{2} \text { loop with } \mathrm{He} \text {-cooled condenser. }\end{array}$ & Since $\sim 1980$ & \\
\hline $\begin{array}{l}\text { NIST reactor, NIST, } \\
\text { U.S. }\end{array}$ & $\begin{array}{l}\text { 20-MW heavy } \\
\text { water }\end{array}$ & $\begin{array}{l}\text { Natural circulation, saturated } \mathrm{H}_{2} \text { loop with He- } \\
\text { cooled condenser. }\end{array}$ & Since -1995 & No significant experience base at NIST for this design. \\
\hline $\begin{array}{l}\text { HFBR at Brookhaven } \\
\text { National Laboratory, } \\
\text { U.S. }\end{array}$ & $\begin{array}{l}\text { 30-MW heavy } \\
\text { water (originally } \\
40 \mathrm{MW} \text {, } \\
\text { upgraded to } 60 \\
\text { then derated to } \\
30 \mathrm{MW} \text { ) }\end{array}$ & $\begin{array}{l}\text { Noncirculating liquid } \mathrm{H}_{2} \text { in moderator chamber } \\
\text { with He cooling tubes on the outside. Unique } \\
\text { feature: moderator vessel purged with } \mathrm{N}_{2} \text { at the end } \\
\text { of each cycle and after any shutdown. }\end{array}$ & $\sim 9$ & $\begin{array}{l}\text { Availability factors over } 95 \% \text { achieved over relatively long periods of } \\
\text { time. Unexpected flaws (e.g., ruptured moderator chamber) have } \\
\text { caused major outages. “... after nine years, the leaming curve for this } \\
\text { facility may not yet have approached its asymptotic limit.” }\end{array}$ \\
\hline
\end{tabular}

${ }^{a}$ G. J. Russell and C. D. West, "International Workshop on Cold Neutron Sources," LA-12146-C (Conference), UC-413, Los Alamos National Laboratory, Los Alamos, New Mexico (March 5-8, 1990).

bJ. M. Astruc and G. M. Gistau, "Analysis of the Reliability of the Refrigeration System used in the Reactor Cold Source at the ILL, Grenoble, after 11 Years of Operation," Proceedings of the Tenth International Cryogenic Engineering Conference (ICEC 10), Helsinki, 1984, (Butterworth, ed.), p. 566. 
An additional safety feature is provided for the BNL cold source. Whenever the cold source source is in an upset condition or needs to be shutdown, the $\mathrm{LH}_{2}$ is flushed out with a sweep of nitrogen gas. As operated in the early years, the arrangement was possibly susceptable to cryogenic accumulation of oxygen inside the moderator vessel and an energetic event occurred, nupturing the moderator vessel. The consequences, other than to the moderator vessel, were not severe and of no particular safety significance. The BNL cold source has been operated since that time with no further energy releases.

The safety and availability record for use of cold sources in reactors, based on the reports at the 1990 Cold Source Workshop, appears to have been quite satisfactory. Additional follow-up is needed to get more details on the minor events that have happened. The one known major event in the more than 100 years of cold source experience is the moderator vessel rupture at BNL. The HFBR cold source design is so unique that it would be unreasonable to conclude that moderator vessel rupture is an anticipated event for cold sources. Nevertheless, since the moderator vessel is always constructed with the thinnest walls technically feasible, the ANS cold source should be designed to accommodate a moderator vessel rupture without adverse consequences to the reactor or personnel.

\subsection{CONVERSATIONS WITH SYSTEM DESIGNERS}

Because the ANS cold source support system design was still evolving at the time of this effort and to ensure that information was being used properly, several informal discussions were held with the cold source designers. During these sessions, the framework for the probabilistic model was constructed by asking the designers questions and postulating various accident scenarios. One of the activities undertaken was obtaining the designers' input regarding their conception of possible accidents leading to a release of deuterium into either heavy water or air. The Cold Source Accident Sequence Definition Scoping Study Questionnaires (see example in Fig. 4.1) were compiled in a data base and categorized by accident type. The information from this data base is presented in the MLD discussion in Sect. 5.

\subsection{DATA SOURCES}

\subsubsection{Generic Failure Data References}

The specialized nature of cryogenic components requires that input data be screened for applicabilty. The environmental influences on a motor-operated valve or pump in a service water system will not be as extreme as those in a system with temperatures ranging from room temperature to near $20 \mathrm{~K}$. As a consequence of previous availability studies related to the cold source systems, ${ }^{3}$ a small collection of cryogenic and refrigeration-related equipment performance data were assembled. ${ }^{4,5,6}$

As presented in Sect. 4.1, there also exists at least 100 years of operating experience with various cold sources around the world. Together, these sources can provide ample information pertaining to the reliability and mean time to failure of cryogenic and related equipment.

\subsubsection{Consideration of Multiwalled Piping Failure}

Reference 7 provides some discussion of multiwalled piping in cryogenic applications. This practice is quite common because of the need to provide a vacuum insulation barrier between the circulating fluid and

the atmosphere primarily to reduce heat transfer but also to prevent pipe stress caused by frozen gas building up on the outside of the pipe. The ANS cryogenic piping adds a third barrier filled with pressurized inert gas to aid in the detection of leaks either into or out of the piping. According to ref. 7, each additional wall reduces the probability of failure by a factor of approximately 10 below the likelihood of single pipe failure. The walls of this piping are very thin, but the use of multiple concentric walls serves to strengthen the pipe 
overall. This strengthening combined with the relatively short circulating loop minimizes the contribution to overall risk from pipe breaks. Further structural analysis and testing should be performed to better define the strengths and vulnerabilities of this piping.

Cold Source Accident Sequence Definition Scoping Study Questionnaire

This sheet applies to the following failure:

DEFINITION of the Postulated Failure:

Severity: (for boundary failures, the leak flow area):

Location:

Approximate Frequency: Anticipated ( $>10^{-2 / y e a r) ; ~ U n i b k e t y ~}\left(10^{-2 / y}<f<10^{-1 / y}\right)$; Extremely Unikely $\left(10^{+}<1<10^{-4} / y\right)$

Associated or Consequent Failures: (additional failures that could be expected to come with or be caused by the postulated failure)

SUCCESS PATH(S) available either automatically or manually by which the cold source may be brought to a safe shutdown state with inventory adequately controlled are listed - please list all success paths - for each path list only the minimum set of equipment functions and/or operator actions that must take place to prevent and/or mitigate damage.

\begin{tabular}{|c|c|c|c|}
\hline $\begin{array}{c}\text { Success Path Functional } \\
\text { Definition }\end{array}$ & $\begin{array}{c}\text { Active Equipment } \\
\text { Functions or Operator } \\
\text { Actions Required }\end{array}$ & $\begin{array}{c}\text { Effect of single active } \\
\text { failure on success path } \\
\text { (e.g., valve doesn't open) }\end{array}$ & $\begin{array}{c}\text { Phenomenological } \\
\text { Uncertainties or } \\
\text { calculations needed. }\end{array}$ \\
\hline 1 & & & \\
\hline 2 & & & \\
\hline 3 & & & \\
\hline
\end{tabular}

Fig. 4.1. Designer input sheet for accident scenarios.

As shown in Fig. 4.2, the moderator vessel extends into the inner beam tube, supported only by the inlet and outlet piping (supply and return are contained within the same piping assembly). Finite element analyses were performed to identify weak spots and stress raisers. 


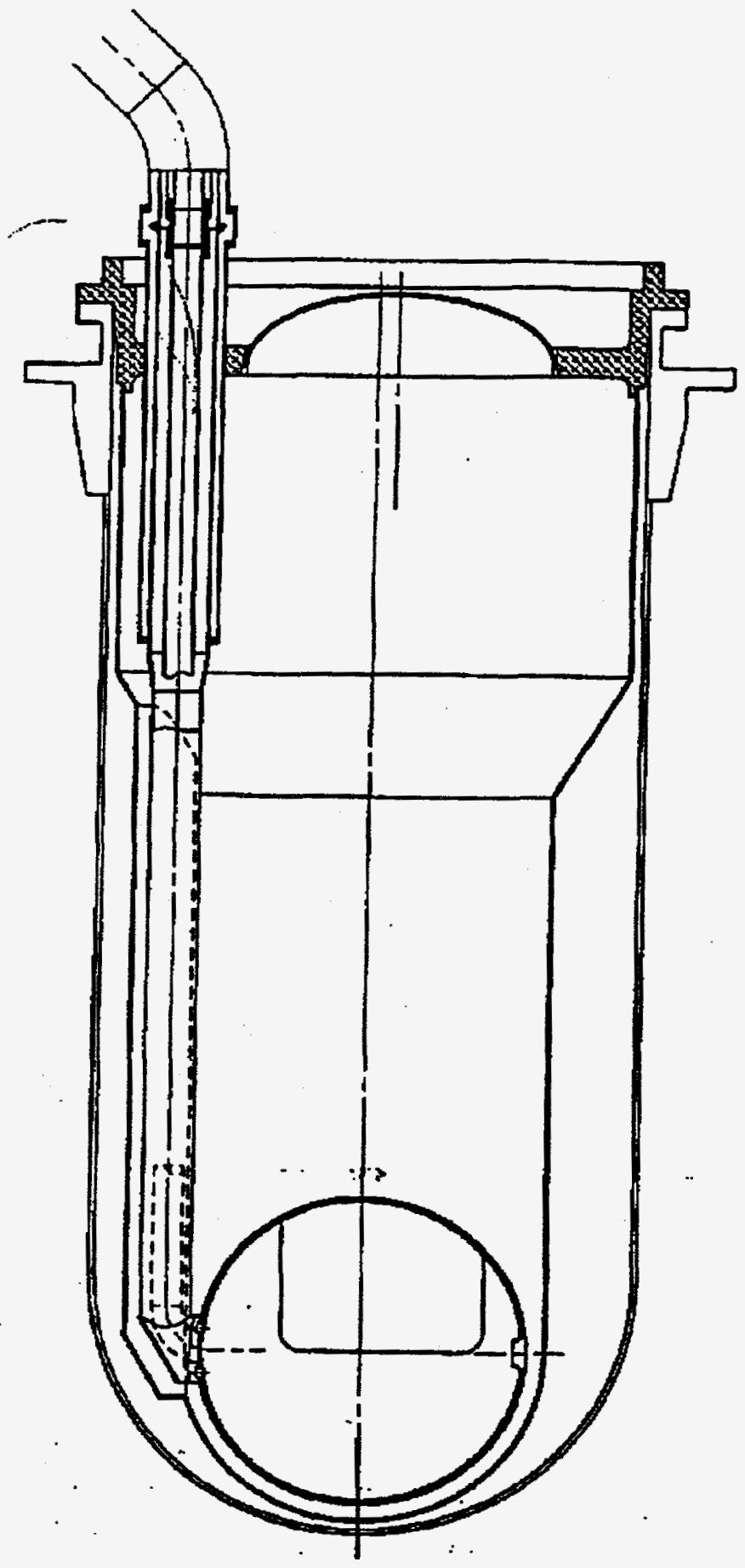

Fig. 4.2. Cut-away view of the cold source beam thimble and internals showing the $D_{2}$ moderator vessel (left) and concentric inlet/outlet piping. The half-elipse object at right is a neutron window. 


\section{PRELIMINARY MODELING AND SELECTION OF INITIATING EVENTS}

\subsection{INTRODUCTION}

The undesireable outcome of any event/accident involving the cold sources would be the release of deuterium to either air or water. If this were to occur, there is a risk for potentially violent reactions (explosions or thermal reactions) as well as for releasing tritium to the containment building. Because of the potential for these events, features such as the dedicated safety-room ventilation system, redundant liquid deuterium circulators, multijacketed piping, and emphasis on containment were incorporated into the design of both cold sources. One of the purposes of the discussions with the cold source system designers (see Sect. 4.2) was to compile a list of detrimental occurrences that could challenge the ability to maintain cold source boundary integrity. Table 5.1 contains a compilation of the accident initiator information provided by the cold source designers. Detailed event frequency calculations have not been performed for these scenarios; thus, the information presented in column three of Table 5.1 is based on conversation with the designers and on the authors' judgement. The event number corresponds to the initiating event categories of the MLD discussed in Sect. 5.2. Further discussion about each event is contained in Sect. 5.2, in addition to the expected and unmitigated results listed for each event in Table 5.1.

\subsection{MASTER LOGIC DIAGRAM AND INITIATING EVENT CATEGORIZATION}

To facilitate the identification of event concerns, an MLD for cold source accident scenarios was constructed. The MLD uses only "OR" logic gates to depict the direct path to the top-level event. The "AND" logic gate would be used in later system top event trees to model failure combinations necessary to reach one of the MLD low-level events. In Fig. 5.1, the MLD shows the various event paths thought to lead to an "escape" of deuterium from the cold source system(s). (Keep in mind that there are two cold sources, allowing for twice the likelihood of occurrence of an event than with a single cold source.) The second-level MLD events represent the categories of cold source events that have the potential to result in an escape of deuterium to the building atmosphere. Below the second level, the event definitions are more specific and relate to loss of a support system, boundary integrity, function, or process failure. The ensuing paragraphs contain more detailed discussion of these events.

The root cause of any of these events can vary from a fault within a single component to human errror or a seismic event. Ultimately, there must be a failure of the final layer of deuterium containment before an escape of gas could occur. However, the path leading up to the containment failure can vary from insufficient boundary cooling or boundary failure to an unmitigated pressure increase or gas transfer mishap. Many of the event scenarios represented in the MLD were also addressed in the ANS Conceptual Safety Analysis Report: ${ }^{8}$ 
Table 5.1 Cold source accicent scenario identification

\begin{tabular}{|c|c|c|c|c|}
\hline $\begin{array}{l}\text { Event } \\
\text { number }\end{array}$ & Accident/initiator & $\begin{array}{l}\text { Frequency } \\
\text { category }\end{array}$ & Expected result & Unmitigated result \\
\hline 1.1 & $\begin{array}{l}\text { Loss of heavy water cooling } \\
\text { effectiveness (flow lost or } \\
\text { degraded) }\end{array}$ & A & $\begin{array}{l}\text { Assumed low flow alarm with } \\
\text { automatic reactor power reduction } \\
\text { or shutdown. }\end{array}$ & $\begin{array}{l}\text { Possible loss of beam tube thimble } \\
\text { integrity because of overheating. If } \\
\text { thimble breach occurs in conjunction } \\
\text { with additional failures, possible } \\
\text { uncontrolled release of } D_{2} \text {. }\end{array}$ \\
\hline 1.2 & $\begin{array}{l}\text { Loss of refrigeration ( } \mathrm{He} \\
\text { refrigeration system } \\
\text { unavailable) }\end{array}$ & A & $\begin{array}{l}\text { Reactor scram and circulator trip } \\
\text { on high } \mathrm{LD}_{2} \text { temperature and } \\
\text { pressure. Control valve opens to } \\
\text { relieve pressure to } 30 \mathrm{~m}^{3} \text { expansion } \\
\text { vessel. }\end{array}$ & $\begin{array}{l}\mathrm{LD}_{2} \text { boiling in the moderator vessel } \\
\text { above } 29 \mathrm{~K} \text {. Relief valve or rupture disk } \\
\text { assumed to vent } \mathrm{GD}_{2} \text { to } 60 \mathrm{~m}^{3} \text { vent } \\
\text { vessel, else pressure-related failure of } \\
\text { moderator vessel. }\end{array}$ \\
\hline 1.3 .1 & Loss of $\mathrm{D}_{2}$ forced circulation & A & $\begin{array}{l}\text { Startup of redundant circulator or } \\
\text { reactor scram if start fails. Note: } \\
\text { early failure registers will be } \\
\text { established by the } \\
\text { circulator test program. } \\
\text { This will allow a change to } \\
\text { the spare circulator early } \\
\text { enough to be controlled. Venting to } \\
\text { expansion vessel as } \mathrm{LD}_{2} \text { warms. }\end{array}$ & Same as 1.2 . \\
\hline 1.3 .2 & Failure of instrumentation & A & $\begin{array}{l}\text { Reactor scram on loss of input from } \\
\text { instrumentation. }\end{array}$ & $\begin{array}{l}\text { Loss of pressure and/or temperature } \\
\text { control for } \mathrm{LD}_{2} \text { circulating system. }\end{array}$ \\
\hline 1.3 .3 & Blockage of $\mathrm{D}_{2}$ flow & $\mathbf{U}$ & Similar to circulator failure. & See forced circulation failure. \\
\hline 1.4.1 & $\begin{array}{l}\text { Moderator vacuum system } \\
\text { failure (either vacuum control } \\
\text { or intemal boundary failure) }\end{array}$ & $A U^{b}$ & $\begin{array}{l}\text { Reactor scram and } \mathrm{LD}_{2} \text { circulator } \\
\text { trip on high temperature and } \\
\text { pressure. Relief valves open to } \\
\text { relieve pressure to expansion } \\
\text { vessel. }\end{array}$ & $\begin{array}{l}\text { If gross loss of vacuum, boiling in the } \\
\text { moderator could occur as well as } \\
\text { possible freezing of } D_{2} O \text { between } \\
\text { thimbles. }\end{array}$ \\
\hline 1.4 .2 & Vacuum vent vessel failure & A & $\begin{array}{l}\text { Action at operator discretion } \\
\text { following indication in cold source } \\
\text { control room (i.e., the vent vessel } \\
\text { functions only during an } \\
\text { emergency situation when it is } \\
\text { required to provide a safe } \\
\text { repository for vented } D_{2} \text { ). }\end{array}$ & $\begin{array}{l}\text { Highly dependent on specifies. If the } \\
\text { vent tank were allowed to fill with air } \\
\text { prior to an emergency } D_{2} \text { venting. } \\
\text { explosion or burning could result. }\end{array}$ \\
\hline 1.4 .3 & Safety window failure & $\mathrm{U} / \mathrm{EU}^{b}$ & Loss of vacuum. & $\begin{array}{l}\text { Loss of vacuum uniess accompanied by } \\
\text { inner thimble or moderator vessel } \\
\text { failure. }\end{array}$ \\
\hline 1.5 & $\begin{array}{l}\text { Loss of off-site power (loss of } \\
\text { He fridge, circulator pumps, } \\
\text { vacuum pumps, thimble } \\
\text { cooling pumps) }\end{array}$ & A & $\begin{array}{l}\text { Reactor scram and } L D_{2} \text { circulator } \\
\text { trip on high temperature and } \\
\text { pressure. Control valve opens to } \\
\text { relieve pressure to expansion } \\
\text { vessel. }\end{array}$ & $\begin{array}{l}\mathrm{LD} \mathrm{D}_{2} \text { boiling in the moderator above } 29 \mathrm{~K} \text {. } \\
\text { Relief valve or rupture disk assumed to } \\
\text { vemt } \mathrm{GD}_{2} \text { to vemt tank. Heat input from } \\
\text { reactor not as high because of dropping } \\
\text { outer shutdown rods. }\end{array}$ \\
\hline 2.1 & Moderator vessel integrity & & Inner thimble vacuum space fills & Possible $\mathrm{D}_{2} \mathrm{O}$ freezing on inner thimble. \\
\hline
\end{tabular}

with gaseous $D_{2}$. Initial $D_{2}$ pressure decrease followed by venting to the expansion vessel. Reactor scram. 
Table 5.1 (continued)

\begin{tabular}{|c|c|c|c|c|}
\hline $\begin{array}{l}\text { Event } \\
\text { number }\end{array}$ & Accident/initiator & $\begin{array}{l}\text { Frequency } \\
\text { category }\end{array}$ & Expected result & Unmitigated result \\
\hline 2.2 & $\begin{array}{l}\text { Component seal failure } \\
\text { (safety room) }\end{array}$ & $\mathrm{A} / \mathrm{U}^{b}$ & $\begin{array}{l}\text { Slow leak may not be noticed by } \\
\text { system. Reactor scram on low } \\
\text { pressure possible after some time. } \\
\text { Vent isolation and gas recombining } \\
\text { system will be demanded if second } \\
\text { equipment seal fails. }\end{array}$ & $\begin{array}{l}\text { Could affect component performance } \\
\text { (pump/valve) as well as } \\
\text { overpressurization of seal leading to } \\
\text { release to safety room. }\end{array}$ \\
\hline 2.3.1 & $\begin{array}{l}\mathrm{LD}_{2} \text { transfer line failure in } \\
\text { safety room (including heat } \\
\text { exchanger tube leak) }\end{array}$ & $\mathrm{U}$ & $\begin{array}{l}\text { Low } \mathrm{LD}_{2} \text { pressure scram, pump } \\
\text { coastdown, loss of vacuum. Unless } \\
\text { vacuum jacket and inert gas barrier } \\
\text { failure also occurs, no safety threat; } \\
\text { then up to gas handling system in } \\
\text { safety room. }\end{array}$ & $\begin{array}{l}\text { Contamination of helium refrigerant } \\
\text { once pressure equalizes if heat exchanger } \\
\text { tube leak. Helium is normally at a higher } \\
\text { pressure than } \mathrm{D}_{2} \text {. }\end{array}$ \\
\hline 2.3 .2 & $\begin{array}{l}\text { Line failure in area between } \\
\text { safety room and shield plug }\end{array}$ & $\mathrm{EU}$ & $\begin{array}{l}\text { Reactor scram on low } L D_{2} \\
\text { pressure, pump coastdown, loss of } \\
\text { vacuum. }\end{array}$ & $D_{2}$ release to experiment room. \\
\hline 2.3.3 & $\begin{array}{l}\text { Light water transition } \\
\text { assembly integrity failure }\end{array}$ & $\mathrm{U}$ & $\begin{array}{l}\text { Beam tube isolation, manual } \\
\text { reactor scram on potential to } \\
\text { violate containment. }\end{array}$ & Potential to flood beam room. \\
\hline 2.5 & Outer thimble integrity failure & EU & $\begin{array}{l}\text { Leakage noted before large leak } \\
\text { rate develops. Reactor shutdown. }\end{array}$ & $\begin{array}{l}\text { Potential loss of inner thimble and } \\
\text { moderator vessel caused by overheating. }\end{array}$ \\
\hline 2.6 & Inner thimble integrity failure & $\mathrm{U}$ & $\begin{array}{l}\text { Leakage noted before large leak } \\
\text { rate develops. Reactor shutdown. }\end{array}$ & $\begin{array}{l}\text { Helium or } \mathrm{D}_{2} \mathrm{O} \text { loss to inner thimble } \\
\text { vacuum (see 1.4.1). }\end{array}$ \\
\hline 3.2 & $\begin{array}{l}\text { Inert gas system failure (lose } \\
\text { helium pressure or, if } \\
\text { breached, would result in 1.3) }\end{array}$ & A & $\begin{array}{l}\text { Enter Tech Spec limiting } \\
\text { conditions for operation with } \\
\text { possible manual shutdown. Loss of } \\
\text { helium cover gas and or loss of } \\
\text { vacuum. }\end{array}$ & $\begin{array}{l}\text { Higher potential for air ingress or } D_{2} \\
\text { egress caused by loss of barrier. }\end{array}$ \\
\hline 4.3 & Loss of $\mathrm{LD}_{3}$ pressure control & A & $\begin{array}{l}\text { Reactor scram on low pressure, } \\
\text { venting to expansion vessel, } \\
\text { possible boiling in moderator. }\end{array}$ & $\begin{array}{l}\text { Boiling in moderator vessel could lead to } \\
\text { leaks should relief mechanisms fail. }\end{array}$ \\
\hline
\end{tabular}

"Frequency category key: A-anticipated, U-unlikely, EU-extremely unlikely.

${ }^{b}$ Larger range given to indicate that the expected frequency will vary with the severity of the event. 


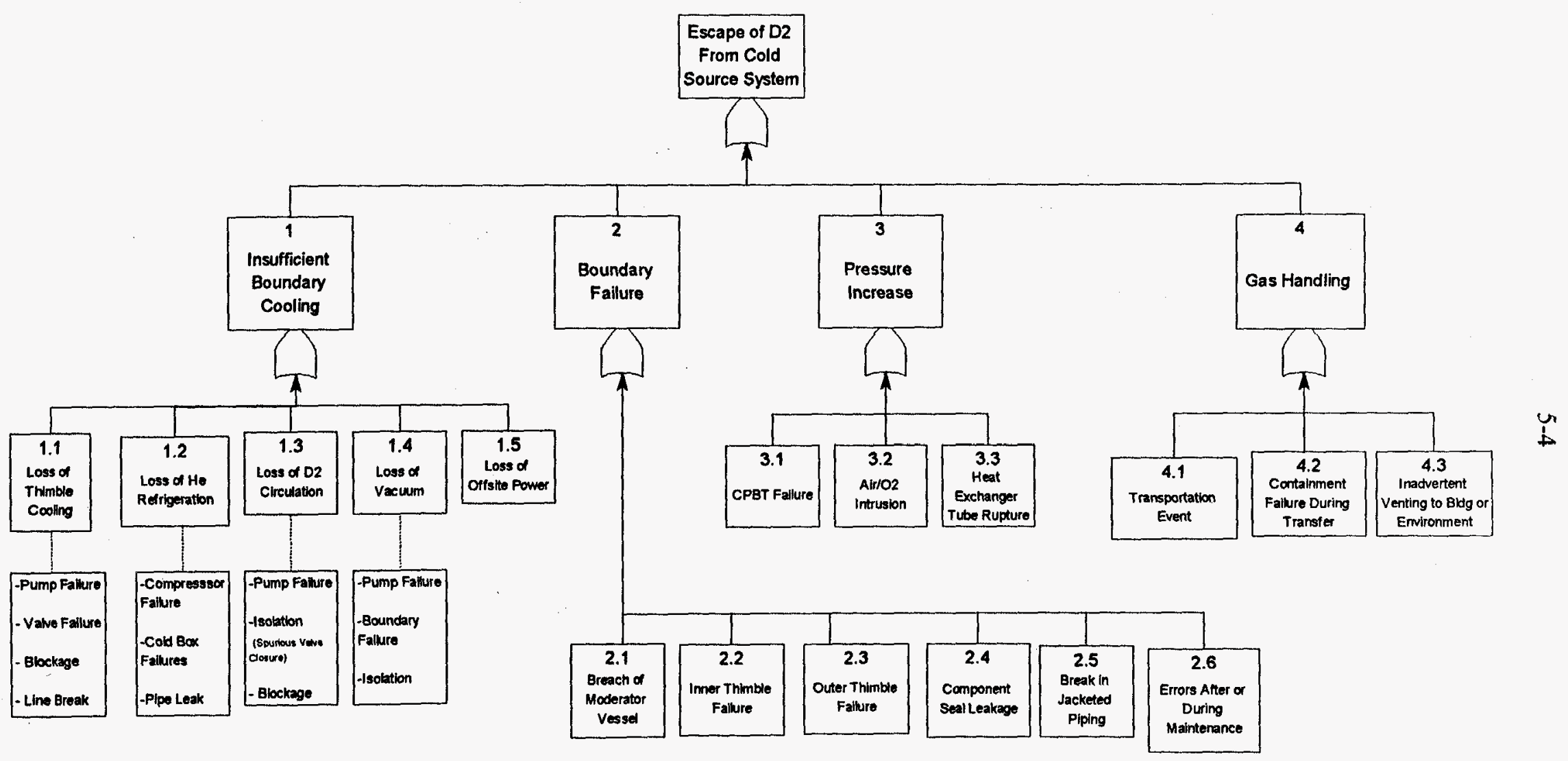

Fig. 5.1. Cold source master logic diagram. 


\subsubsection{Insufficient Boundary Cooling Scenarios}

Because of the extremely cold temperatures desired for continuous operation of the cold sources, minimizing or eliminating the influx of heat from the surrounding environment is very important to maintain steady-state conditions. The primary source of heat is, of course, penetrating gamma and neutron irradiation from the reactor core situated some $250 \mathrm{~mm}$ away from the cold source outer thimble. Other heat sources are the $\mathrm{D}_{2}$ circulator pumps and the radiant heat transfer from the surrounding pipe walls or inner thimble, and, if the vacuum barrier is compromised, convective heat transfer from the surrounding boundaries.

All or most of the events that represent a loss of boundary cooling are tied to a reactor control action or data acquisition system annunciator that would signal the initiation of an insufficient boundary cooling (IBC) scenario. Thus, for the scenario sequence to continue, subsequent failure of automatic and/or manual control actions is required. Reactor scram can be accomplished by either of two redundant and diverse scram systems. The Phase 1 Level I ANS PRA evaluated the failure of the automatic reactor scram function, given a successful scram signal, to be on the order of $10^{-} 6$ for failure of the primary scram system, and $10^{-4}$ for failure of the secondary scram system. ${ }^{9}$

Figure 5.2 depicts a preliminary event sequence diagram (ESD) for the events classified as loss of boundary cooling. The sequence flows from left to right, with an answer of "success," or, "yes" proceeding to the right and "failure," or, "no" going down to the next block in the ESD. A single ESD is used to represent the five boundary cooling event classes because the responses to all are similar. As all systems were designed with some level of redundancy, the first question asked in the event sequence is whether the redundant equipment started and ran. (In the case of loss of off-site power, redundant ac-powered equipment is guaranteed unavailable because, at this point, no cold source equipment is designed to be powered by the diesel generators.) The answer to this and every question in the ESD is in the form of a conditional probability determined through failure analyses. From a safety standpoint, if the redundant equipment is available or if the reactor successfully scrams on the exceeding of cold source safety parameters, the scenario is said to be mitigated. If the event sequence is not terminated by start of a redundant component or automatic protective action, the availability of the $\mathrm{D}_{2}$ circulators and the adequacy of normal venting to the expansion vessel can have a positive impact on the ability to maintain system integrity, preventing a release of $\mathrm{D}_{2}$. From this point, the final sequence end states are determined by the adequacy of the various levels of containment and pressure relief. If the event progresses to the point where no action has been taken and normal venting to the expansion vessel is insufficient to contain the expanding deuterium, there still remain three layers of containment, each with its own dedicated relief mechanism(s) that would have to fail before releasing $\mathrm{D}_{2}$ gas to the immediate surroundings. This ESD is intended as an example of the type that would need to be produced for each category of events in the preceding MLD.

\subsubsection{Loss of Thimble Cooling}

Approximately $30 \mathrm{~kW}$ of heat is assumed (for design purposes) to be transferred through the thimble assembly (outer thimble, annulus, inner thimble) to the cold source moderator vessel. Figure 5.3 shows a simplified schematic of the primary cold source heat loads during operation. The forced convective cooling 


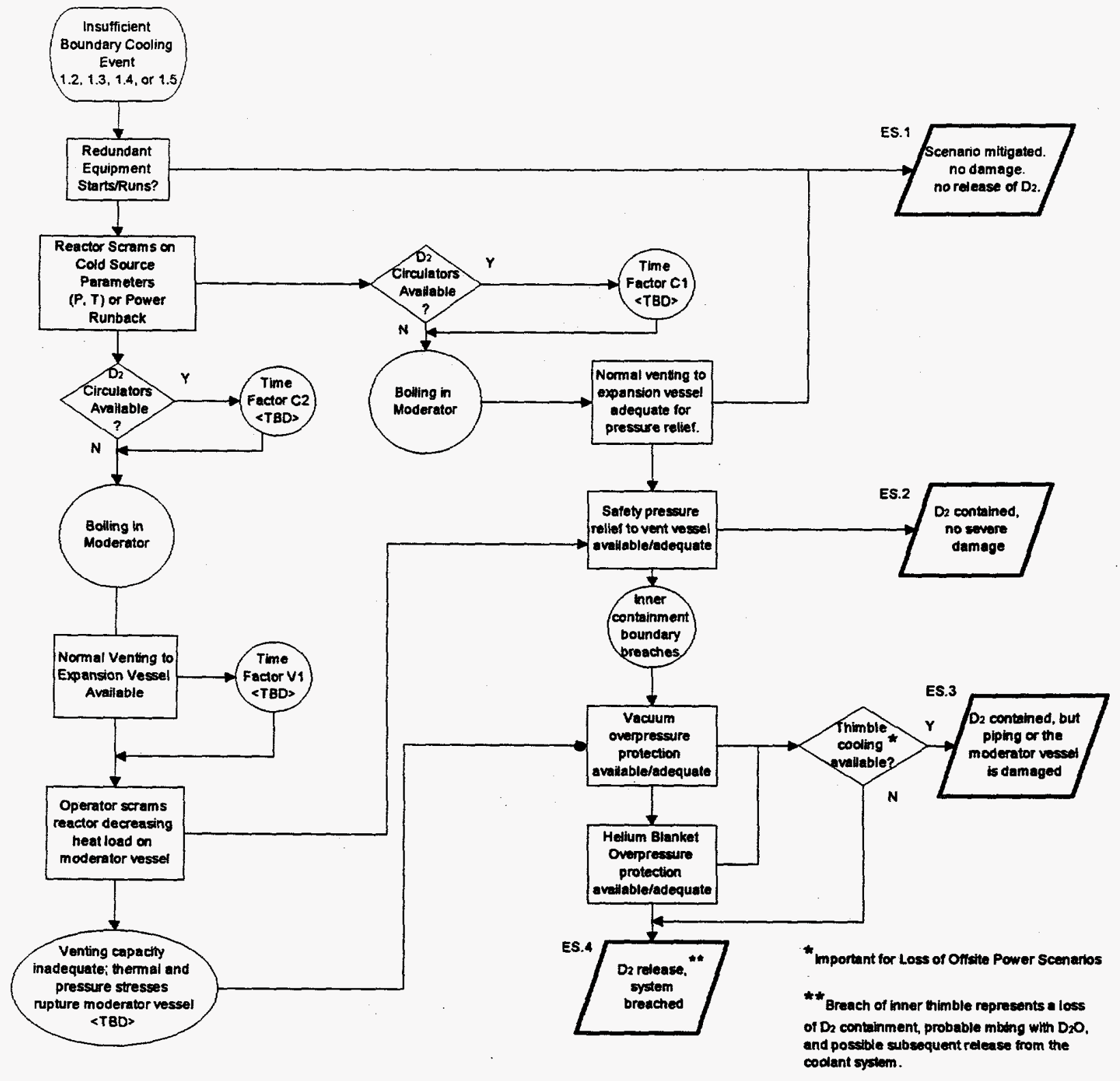

Fig. 5.2. Loss of boundary cooling event sequence diagram.

that takes place between the inner and outer thimbles greatly reduces the amount of heat deposited in these components and thereby reduces the radiant heat available for transfer to the moderator vessel from the inner thimble.

The first failure after a loss of thimble cooling is likely that of the inner thimble, caused by overheating; this constitutes a loss of thimble vacuum. An unmitigated loss of thimble cooling could lead to boiling in the moderator vessel, pressure fluxuations in the $\mathrm{LD}_{2}$ circulator system, and damage to the moderator vessel.

For purposes of frequency estimation, it is assumed that the thimble cooling system for each cold source begins where water is removed from the reflector vessel cooling system cold leg at a branch line; from there it travels through a series of valves and one of two redundant pumps, another set of valves, and the cold source 


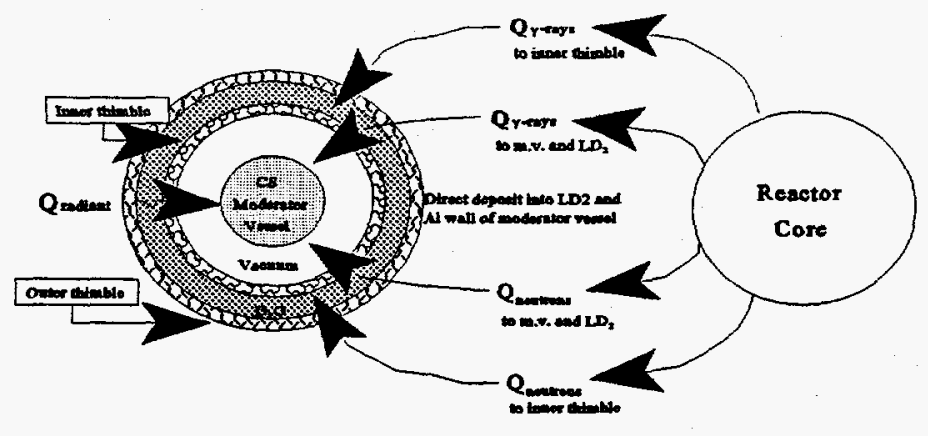

Fig. 5.3. Simplified cold source heat load schematic.

thimbles and then returns to the reflector vessel hot leg. Using component failure data from the ANS PRA, ${ }^{9}$ the frequency of this event for either of two cold sources may be calculated as follows:

$$
\begin{gathered}
F(L T C)=2 \text { ColdSources } \times[(4 \times \text { ZIVMOT } \times 6000 \mathrm{~h} / \text { year })+(Z I P M O R \times 6000 \mathrm{~h} / \text { year } * \\
(Z I P M S S+Z I P M S R \times 6000 \mathrm{~h} / \text { year }) / 2)],
\end{gathered}
$$

where

LTC $=$ loss of thimble cooling events per operating year,

ZIVMOT $=$ motor-operated valve (at least four are assumed in each system) transfers closed (per hour),

ZIPMOR = normally operated motor-driven pump fails during operation (per hour),

ZIPMSS = standby motor-driven pump fails to start on demand (per demand),

ZIPMSR = Standby motor-driven pump fails during operation (per hour):

At least $6000 \mathrm{~h}$ of thimble cooling system operation are assumed during each reactor operating year. The final factor considers that the operating pump fails halfway through the mission time of 1 year of operation, thus demanding the standby pump function for the remainder of the mission. This is somewhat conservative in that no allowance is made for repair and return to service. The final equation, then, is

$$
F(L T C)=2 \times(4 \times 9.3 E-8 \times 6000)+(3.4 E-5 \times 6000 \times(3.3 E-3+3.4 E-5 \times 6000 / 2))=0.047,
$$

Based on these results, the thimble cooling function for one of two cold sources is estimated to fail at a rate of 0.05 per year. This failure rate is exclusive of any thimble cooling unavailability resulting from a loss of offsite power, which causes loss of many systems, as well as a reactor shutdown, and which has its own frequency of occurrence. It is not anticipated that the thimble cooling booster pumps would be backed by an uninterruptible power source for continued operation following a loss of power.

A preliminary event sequence diagram for the loss of thimble cooling event is presented in Fig. 5.4. The goal of each event sequence is to contain the deuterium. The five sequence end states shown in Fig. 5.4 represent the stages of damage perceived for loss of thimble cooling events ranging from complete mitigation to a release of tritiated deuterium with at least moderator vessel failure. Each event sequence begins by first 
establishing the nature of the loss of thimble cooling (like break or equipment failure). If not a line break, it is anticipated that based on the design philosophy for all other systems and the importance of maintaining thimble cooling, redundant equipment would be started. Beyond this, the most critical event is a reactor scram, required if the loss of thimble cooling is caused by a line break or if redundant equipment is not available on demand. The remaining events in the ESD deal with the potential for boiling deuterium in the moderator vessel and the availability of the various stages of pressure relief to prevent release of $D_{2}$ to the surroundings. The estimated frequency of a loss of thimble cooling and the low likelihood of a failure to scram the reactor make reaching the undesireable end states of moderator breach with or without a release of deuterium very unlikely.

\subsubsection{Loss of Helium Refrigeration}

A loss of helium refrigeration (not from loss of power) could come in the form of partial or total unavailability of the helium compressors ( 2 normally operating, 1 standby) or other failure within the refrigeration loop (e.g., turbo-expander failure or line rupture). This event will result in a gradual warming of the entire $\mathrm{LD}_{2}$ inventory and possible boiling in the moderator vessel if reactor control does not respond promptly to reduce power or shut down the reaction. Expansion of the deuterium will follow with demands placed on the inventory control and pressure control mechanisms of the circulating system.

\subsubsection{Loss of Liquid Deuterium Circulation}

Loss of circulation without successful switchover to the standby circulator should result in a reactor scram. Given the unlikely failure to scram compounded by an already unsuccessful swap to the spare circulator, the liquid deuterium in the moderator vessel will quickly heat to boiling, increasing pressure within the system and placing demands on the exit valve to the $30-\mathrm{m}^{3}$ vessel (since all liquid would be expelled by the increased specific volume of the vessel deuterium) and possibly the rupture disk, not to mention the integrity of the moderator vessel.

\subsubsection{Loss of Circulator Loop Vacuum (not boundary failure)}

Failure of the vacuum pumps (both normally operating and standby) accompanied by subsequent failure of check valve closure could lead to a loss of vacuum insulation in the affected region of the liquid deuterium circulation loop, that is, either the loop itself or the region within the inner thimble. If vacuum were degraded or lost, there would be an increase in the heat input to the $\mathrm{LD}_{2}$ followed by an increase in temperature and pressure. The combined probability of the events required for this scenario make a loss-of-vacuum scenario very unlikely but one that protection systems are designed to handle.

\subsubsection{Loss of Off-Site Power}

A loss of off-site power (LOSP) would result in nearly all of the previously mentioned scenarios (a true loss of vacuum is dependent on other events because the vacuum would continue to hold for a significant time after the LOSP) and would lead to warming and expansion of the liquid deuterium. The demands on the cold source system boundaries would be great following a LOSP because all helium compressors, vacuum pumps, $\mathrm{LD}_{2}$ circulating pumps, and thimble cooling pumps would have stopped. 


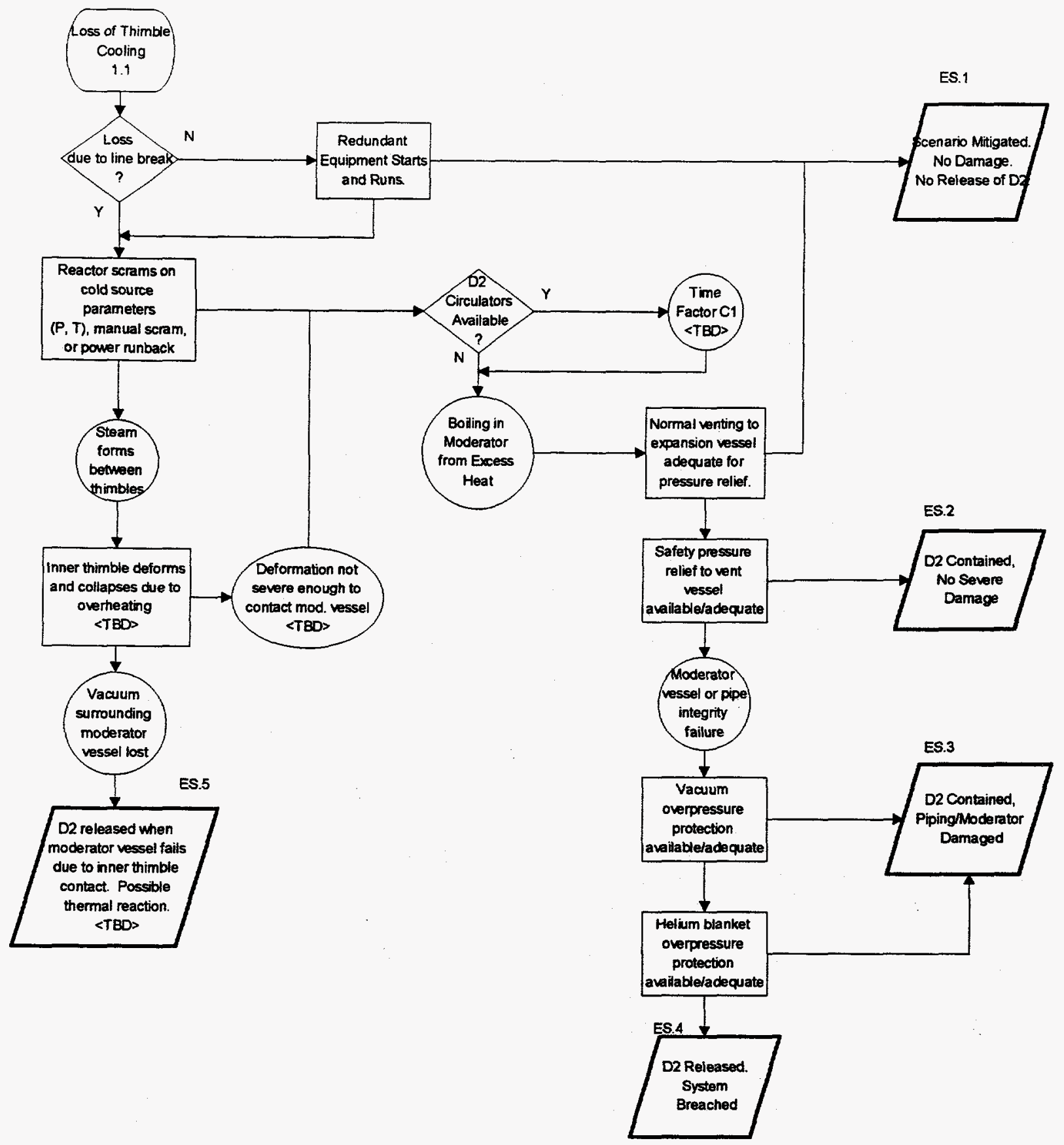

Fig. 5.4. Loss of thimble cooling event sequence diagram.

A complete loss of off-site power (LOSP) will result in a reactor scram signal from the experiment protection system to both the primary and secondary reactor scram systems because of violation of cold source parameters. Regardless, however, the shutdown rods of the secondary reactor scram system will insert following a LOSP and coastdown of the reflector cooling pumps, which supply rod withdrawal pressure. The primary reason a LOSP is such a concern is because gamma heating will still provide a considerable heat 
input even after a reactor scram. It is not known at this time if the thimble cooling pumps will be backed with dc pony motors for continued forced flow following an extended LOSP or if natural circulation cooling could be established to maintain thimble integrity.

\subsubsection{Boundary Failure}

Because of the design emphasis on containment, there are no single boundary failures that result in a release of deuterium. However, more favorable conditions for escape of deuterium can result from single boundary failure. A high contributor in this category of scenarios is event 2.6, errors during or after maintenance, where there is a potential for failing to reestablish complete containment following an opening of the system or replacement of a component.

\subsubsection{Breach of the Moderator Vessel}

Failure of the moderator vessel could result from overpressure or an inherent flaw in construction brought to failure under cold temperatures. Events constituting vessel failure range from small leaks to catastrophic rupture. If the breach were a pin-hole size leak or very small crack, the escaping deuterium would likely be drawn as a gas through the inner thimble vacuum pump, which discharges to the normal cold source vent system, the expansion tank. Also, gas analyzers monitor the vacuum systems for deuterium leaks with automatic protection actions. If a larger breach were to occur where liquid deuterium flows into the evacuated inner thimble region, the sudden introduction of cryogenic fluid onto the inner thimble would certainly cause elevated thermal stresses in the wall of the inner thimble and would also result in rapid vaporization) of the deuterium with the potential for pressure buildup. In the hyopothetical case of catastrophic moderator vessel breach with no venting of the vaporized $\mathrm{D}_{2}$, inner thimble pressure could eventually reach nearly $6 \mathrm{MPa}$. For this reason, the thimble vacuum system is designed with $0.4-\mathrm{MPa}$ rupture discs that relieve to the expansion tank. Note that the pressure wave would also propogate back through the cryogenic loop.

The immediate consequences of a moderator breach can vary as well. The primary effect would likely be a change in $\mathrm{LD}_{2}$ pressure and loss of thimble vacuum. Either of these conditions would signal a reactor scram. Were the sudden introduction of $\mathrm{LD}_{2}$ to result in failure of the double-walled inner thimble, there could be a release of $D_{2}$ to the $D_{2} O$ of the inner thimble cooling system, which returns to the letdown tank (that is if the $\mathrm{D}_{2} \mathrm{O}$ does not freeze when the $\mathrm{LD}_{2}$ enters the inner thimble). Therefore, because of the potential for $\mathrm{D}_{2}$ release, the strengths and weaknesses in the inner thimble and moderator vessel, including the configuration of the $\mathrm{LD}_{2}$ inlet and outlet lines, should be further investigated in both design and safety analyses.

Figure 5.5 illustrates the preliminary event sequences possible following a piping or moderator vessel failure. It is most important to scram the reactor following this event to reduce the heat load and prevent deuterium boiling as pressure decreases in the system, that is, if the failure is not catastrophic. It is also important to disable the $D_{2}$ transfer pump to stop system makeup and conserve the deuterium. Additional time to mitigate the event, in some instances, can be bought if the refrigeration system for the affected cold source is available to continually cool the circulating $\mathrm{LD}_{2}$. The redundant pressure relief systems are then relied on to complete the event mitigation and contain the deuterium.

The frequency of this event (moderator vessel breach) is estimated, using ref. 5 , to have a mean likelihood of $4 \times 10^{-5}$ per year. This estimate is so low because of (1) the low-pressure conditions in the system and (2) the relatively short runs of piping in the cryogenic loop. Experience has also shown high reliability with multiwalled piping. 


\section{$5-11$}

\subsubsection{Inner or Outer Thimble Failure}

The inner and outer thimbles represent the second and third layers of containment surrounding the cold source moderator vessel. Both thimbles are subject to high levels of radiation because of their location and are designed to be replaced at two-year intervals. Failure of only one of these components (e.g., a small leak resulting from radiation damage) should pose no risk of releasing deuterium to the containment atmosphere unless a failure in the circulating loop already exists or is imminent. The double-walled inner thimble is under vacuum on the inside and is cooled by $\mathrm{D}_{2} \mathrm{O}$ on its outer surface. As such, the primary force on the thimble is compression from the cooling water that flows in the annular space between the inner and outer thimbles. If the inner thimble developed a crack, $\mathrm{D}_{2} \mathrm{O}$ would be drawn into the moderator region where the degradation of vacuum would signal a reactor scram. Any freezing of water on the moderator vessel could result in local thermal instability problems within the vessel itself, not to mention the added heat input to the $\mathrm{LD}_{2}$.

The outer thimble, as part of the reflector vessel pressure boundary is subject to the design pressure of the reflector vessel and to transient pressure increases above these design pressures (see Sect. 5.2.3.1, "Core Pressure Boundary Tube Failure"). Again, the primary forces acting on this component are compressive from reflector vessel coolant pressure. Because it is part of the reflector vessel pressure boundary, the vulnerability of the outer thimble should be examined further, but as a contributor to release of deuterium to the containment, efforts may be better applied elsewhere.

\subsubsection{Component Seal Leakage}

Components in the deuterium circulating loop (pumps, valves, flanges, etc.) are installed with two metallic seals to ensure that double containment is maintained. Thus, failure of both seals is required for deuterium to escape. All equipment of this nature is located in the safe-room, which is equipped with its own gas-handling system. The main reactor building ventilation system will be ducted to the safe-room; however, if deuterium is detected this duct will be isolated and a closed-loop cleanup system, incorporating a catalytic converter, will remove the deuterium. The deuterium will be converted to heavy water by the catalyst and removed to the detritiation plant in a portable molecular sieve. Any seal leakages should be small enough for the gas-handling systems to manage effectively. The room ventilation will isolate to initiate the start of the special catalytic converter to remove the deuterium from the atmosphere. The risk of combustion is dependent on the concentration of deuterium in the safe-room and the cause of the rupture. This initiator should be investigated if only for the quantitative knowledge of the likelihood of circulator pipe rupture in comparison to other initiators.

\subsubsection{Breach in Transfer Line}

The use of multijacketed piping is common practice in cryogenic applications. Especially common is surrounding the pipe carrying cryogenic fluid with a vacuum barrier to provide insulation and prevent cryopumping of gases onto the line. The tertiary layer provided at ANS allows for monitoring the inert gas for deuterium as well as ensuring containment in the event of a vacuum leak. For deuterium to escape from the transport piping, three layers of containment must be violated. Sections of the transfer lines are not welded but are connected with specially designed sleeves with metal seals to ensure continuation of each layer of containment across the connection (see Fig. 5.6). If anything, the piping is strongest at these connections. 


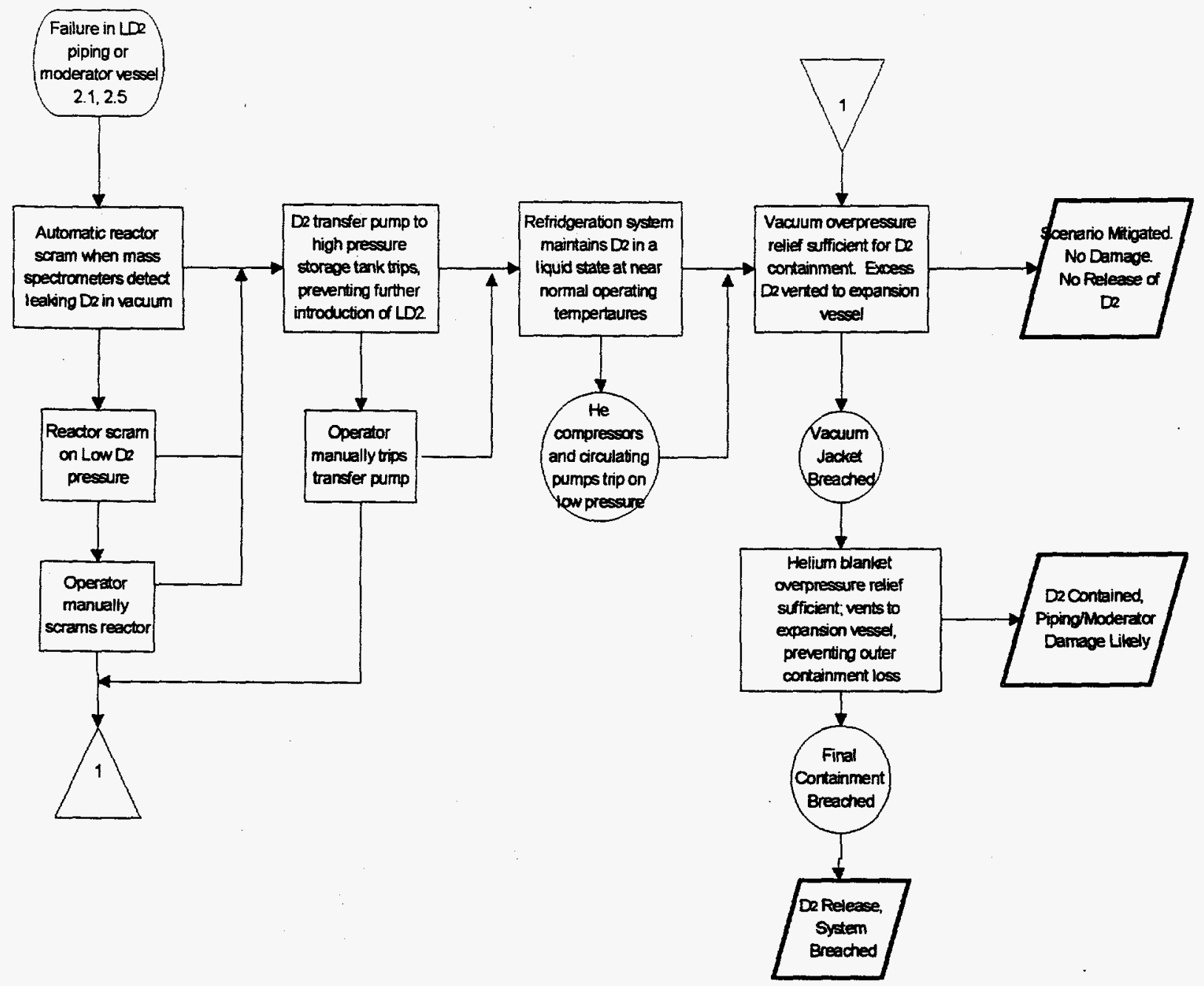

Fig. 5.5. Breach of moderator vessel/circulator piping event sequence diagram.

Reference 7 discusses two viewpoints on failure rates for double-walled tubing. One viewpoint suggests a factor of 0.5 reduction over single-walled piping external leakage reliability, including the common mode effects of vibration, material compatability, and corrosion. However, the piping considered is underground and often carries corrosive material, very different from the $\mathrm{LD}_{2}$ of the cold source, making the 0.5 factor very conservative. The second opinion roughly squares the single-pipe failure rate but does not consider any common mode effects. The authors conclude that a factor of 0.1 times the single-walled leak rate provides acceptable and still somewhat conservative results for double-walled piping external leakage rates. Using this factor in estimating the ANS cold source external leakage rate will provide a somewhat more conservative figure because of the triple-walled piping being used . Reference 7 also examines failure rates for several different tubing materials including stainless steel (leakage failure rate $=1.0 \mathrm{E}-09 / \mathrm{m}-\mathrm{h}$ ). Using an estimate of approximately $25 \mathrm{~m}$ of cryogenic stainless steel piping per cold source, the annual frequency of an external leak from cryogenic piping is

$1.0 \mathrm{E}-09 / \mathrm{m}-\mathrm{h} \times 50 \mathrm{~m} \times 6000 \mathrm{~h} /$ year $=3.0 \mathrm{E}-04 /$ year . 
Again, this is a preliminary and conservative estimate of leakages at this stage in the design. The frequency of larger ruptures of cryogenic piping would likely be $10 \%$ of this value.

The majority of exposed circulator piping is located in the safe-room, which, as noted previously, is equipped with dedicated gas-handling capabilities. It is difficult to conceive of a small leak violating three containment layers and going unnoticed by the monitoring systems. In the event of a pipe rupture (see the ESD in Fig. 5.5), the reactor will be scrammed on low cold source pressure.

\subsubsection{Failure Caused by Errors After or During Maintenance}

Further system design and operations testing would be required to fully examine the human interface with ANS cold source operation and maintenance. However, experience has shown that the human element in critical systems maintenance and operation normally has a higher potential to cause problems than the system components.

\subsubsection{Uncontrolled Pressure Surge}

\subsubsection{Core Pressure Boundary Tube Failure}

The abrupt failure of the core pressure boundary tube (CPBT) would result in a pressure wave traveling through the reflector vessel. As a part of the reflector vessel pressure boundary, the outer cold source beam tube thimble is designed to withstand a transient pressure of $1.35 \mathrm{MPa}^{8}$ such as would be experienced with a sudden CPBT rupture. However, because the thimble thicknesses are minimized to maximize neutron transmission (i.e., thimble walls are very thin), there is some probability of thimble deformation. 

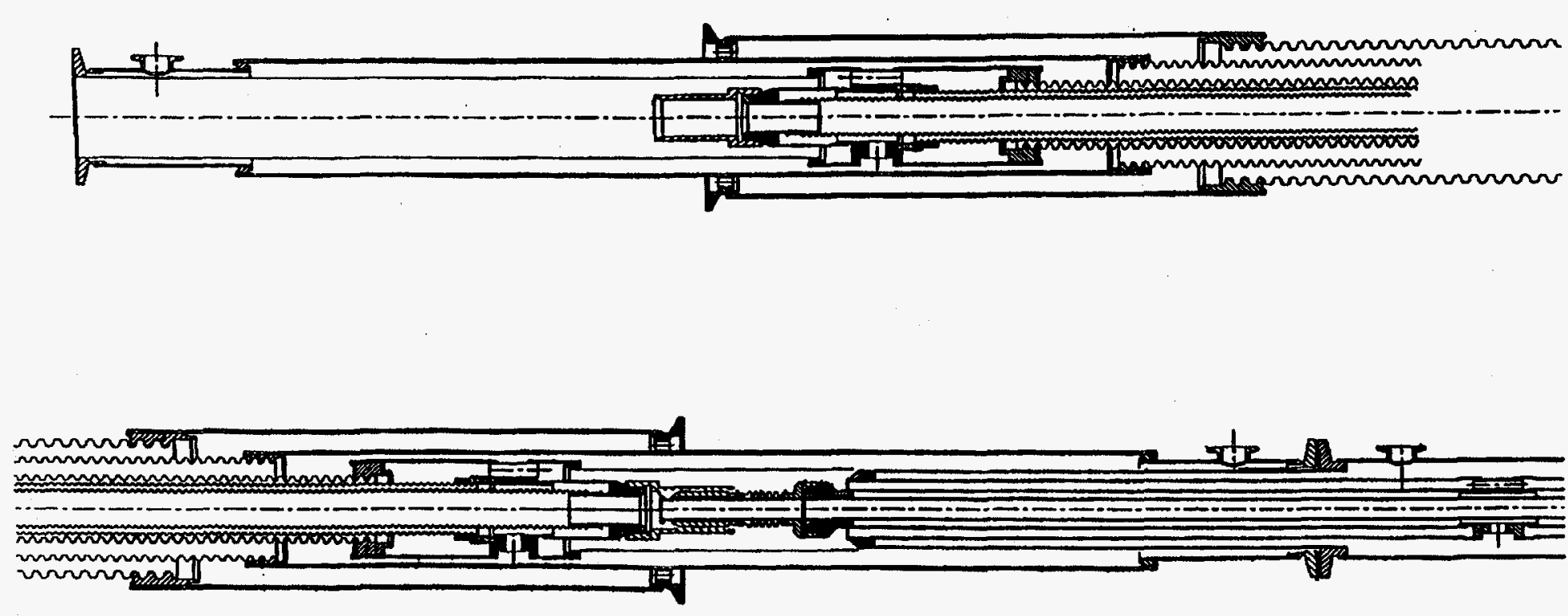
The effect on the cold source moderator vessel(s) can only be speculated at this point. Given that the likelihood of a catastrophic CPBT rupture is very low to begin with, followed by the subseqently low likelihood of beam tube thimble failure and the uncertainty of impact on moderator vessel integrity, this scenario may not warrant further consideration as a design basis accident.

\subsubsection{Air/ $\mathrm{O}_{2}$ Intrusion in Circulator Loop}

Considering the volatility of hydrogen (deuterium) when mixed with air (oxygen), it is very important that conservative measures be taken to prevent introduction of oxygen into the $\mathrm{LD}_{2}$ circulation loop. Even a small amount of oxygen could result in a rather severe reaction and damage to the system. The current system design uses a multiple-containment philosophy throughout, even during transport into the system, minimizing the likelihood of oxygen ingress (refer to the previous discussion on pipe rupture). The ANS has no coolant purge feature like that at the High Flux Beam Reactor, believed to be the source of the air that led to a reaction in that facility. When deuterium is transported to or from portable metal hydride beds into or out of the cold source system, the transfer couplings are designed with a double-containment philosophy to preclude introduction of air during the transfer process. Any oxygen introduced in the system at this point should manifest itself almost immediately, without the chance of entering the $\mathrm{LD}_{2}$ circulating system. Even the metal hydride beds, expansion, and safety storage vessels are sourrounded by double containment with a vacuum between the containment layers. Oxygen inleakage through the circulator piping and components is very unlikely because the intruding gas must pass through three layers of piping as well as monitored layers of helium gas (pressurized above atmospheric) and vacuum blanket prior to reaching the deuterium.

One can easily say that an $\mathrm{O}_{2}-\mathrm{D}_{2}$ reaction in the ANS cold source is a very unlikely event by design and that such a reaction occurring in the cryostat (moderator vessel) is even more unlikely. Although there are other more likely events that will challenge the cold source systems from an operating standpoint, this event should not be eliminated from consideration in the MLD or from evaluation during each stage of any future design work. Sufficient concrete information to evaluate the possible frequency of this event was not available. The wide-ranging consequences of this event would also depend on where in the system the event occurred, another topic too vague to evaluate at this point.

\subsubsection{Heat Exchanger Internal Rupture}

The main heat exchanger is of the plate and fin design and it is surrounded by vacuum and inert gas blankets. Because the helium in the refrigeration system is maintained at a higher pressure than the $L D_{2}, a$ heat exchanger rupture will most likely result in an influx of liquid helium into the affected circulator loop, rather than an escape of deuterium. This event would be detected first by the main heat exchanger pressure difference sensors located in the circulator loop. The most likely consequences of this event are a reactor scram, cold source shutdown, and extended downtime to repair or replace the failed heat exchanger. To date, searches for failure data on cryogenic heat exchangers have not uncovered any specific information related to these components, and is not thought appropriate to use standard heat exchanger or steam generator failure data. Thus, additional data searches would be necessary in the future.

\subsubsection{Gas Transfer Event}

The three scenarios envisaged for gas transfer accidents, transportation event, containment failure during gas transfer, and inadvertent venting have the potential to release deuterium gas directly to the building atmosphere. As described previously, double containment should be maintained throughout all gas transfers, but all transfers involve the often unpredictable human element. Were any of these events to occur, 


\section{PRELIMINARY LIST OF DESIGN BASIS EVENTS FOR THE ANS COLD SOURCES}

The process followed in Sects. 2 through 5 for applying PRA techniques to the selection of DBEs is illustrated in Fig. 1.1 of this report; this section outlines how the complete list of DBEs can be determined. DBEs are listed and designated by frequency category as anticipated events (frequency $>10^{-2} /$ year), unlikely events $\left(10^{-4}<\right.$ frequency $<10^{-2} /$ year $)$, or extremely unlikely events $\left(10^{-6}<\right.$ frequency $<10^{-4} /$ year $)$. As a part of the natural progression of cold source design and analysis, the outcome of each event on the list of DBEs is predicted using an appropriate computer code, hand calculation, or empirical data or is bounded by comparison to a known result. The result is then carefully reviewed and the design declared to be adequate if certain applicable acceptance criteria are met. The acceptance criteria are different for each event frequency category. The most stringent criteria are reserved for the events that are expected to occur the most frequently. This is a standard approach in the nuclear industry. ${ }^{9}$ In addition, applying the most stringent criteria for the most frequent event is the optimum approach to safety and operability because it requires the most mitigation for the events that are the most likely to happen. To ensure a suitably conservative design, the determination of frequency grouping of DBEs is done at a high confidence level ( $>90 \%)$.

\subsection{ACCEPTANCE CRITERIA}

Acceptance criteria for the ANS cold sources have been taken directly, or by analogy, from the Advanced Neutron Source Plant Design, ${ }^{10}$ the top-level requirements document that applies to all ANS systems. The criteria that were taken directly from the PDR include the limits for on-site worker radiation exposure, structural limitations on system boundaries, and the effect of the event on reactor operability. The criteria that were formulated by analogy include the combustible gas releases within the reactor building. The bases for such an extrapolative process are: anticipated events are expected to happen during the life of the plant, so their consequences should be relatively mild; unlikely events are not expected to happen but their occurrence would be credible so their consequences, while significant, should be very limited in nature; and extremely unlikely events are not expected or even credible, but their consequences, although very significant operationally or financially, should not involve severe damage to the reactor or loss of human life. Table 6.1 lists the preliminary ANS cold source DBE acceptance criteria.

When the cold source is shown to meet the acceptance criteria for all the DBEs, an important follow-on task (well beyond the scope of this report) is the definition of licensing basis events. It would be possible to use the DBEs directly, with the most severe event in each frequency category becoming the licensing basis event. That approach, while being realistic physically, might not be best in an overall sense. The reason is that any mitigative system credited in licensing basis safety analyses tends to be declared by the regulatory authority to be safety related and is included in the Technical Safety Requirements. Each of these designations puts on its own special burden of increased cost, record keeping, and operational surveillance. Thus, the selection of licensing basis events from DBEs is primarily a process of deciding which systems, structures, or components may be assumed to fail without compromising the acceptability of the outcome (i.e., which structures, systems, and components are really needed for safety. Acceptance criteria for licensing basis events will be the same as those for DBEs.

\subsection{SELECTING A COMPLETE LIST OF DBES}

The initiating event frequencies (Sect. 5.2.5) provide a partial basis for choosing design basis accidents. Because all of the events mentioned occur at a frequency greater than $1.0 \mathrm{E}-06 /$ year, they are all considered to be DBEs. However, the initiating event combined with successive failures and consequences produces design basis accidents. The associated consequences and the likelihood of reaching them will play an important role 
in the future analysis of specific bounding event sequences. Using point estimates, Fig. 6.1 shows that if one or two additional failures of reasonable likelihood occur before ending the accident sequence, many accident scenarios can be considered beyond design basis.

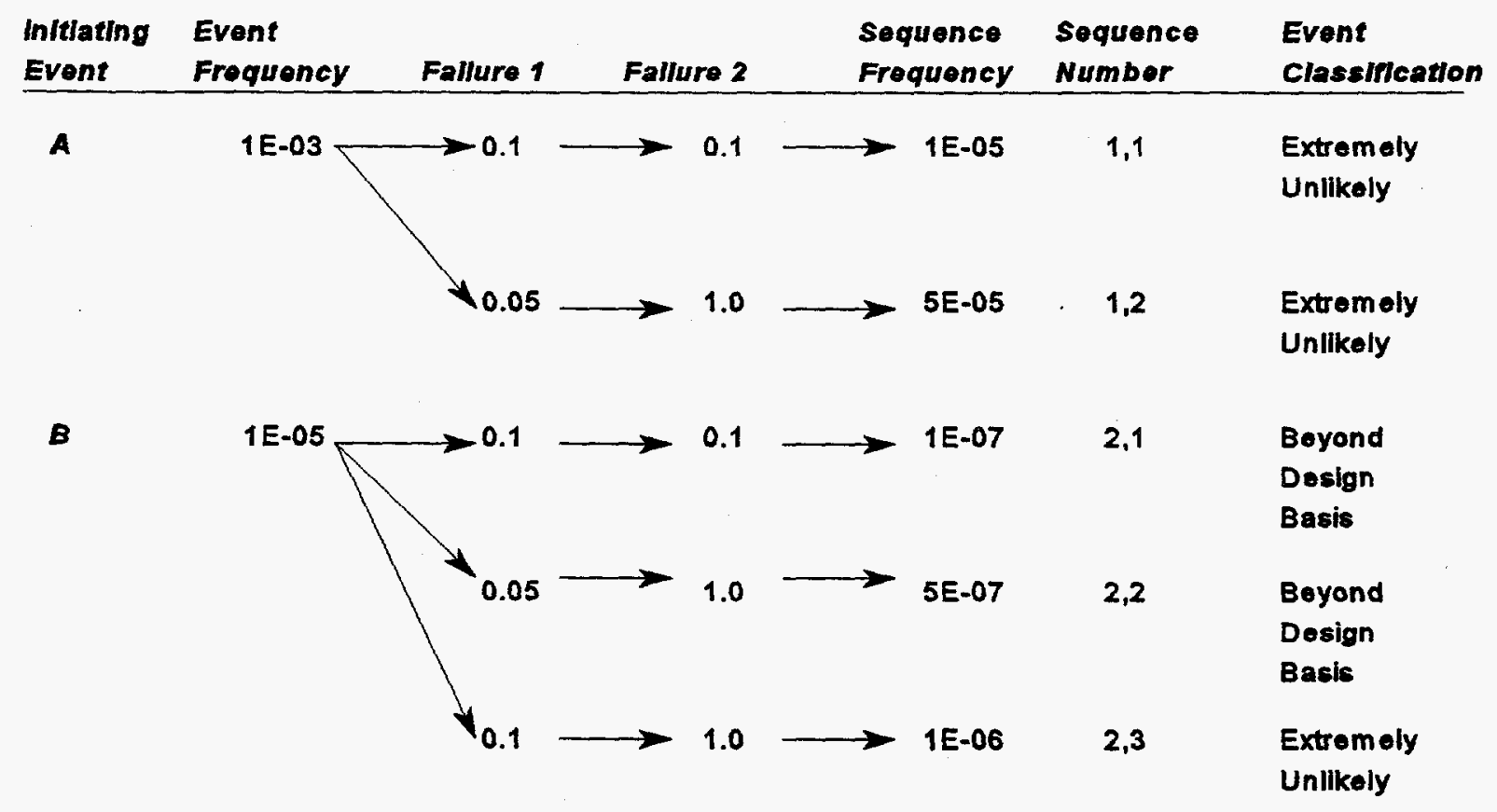

Fig. 6.1. Example of DBE accident sequence categorization. 
Table 6.1. Preliminary acceptance criteria for ANS design basis event analysis

\begin{tabular}{|c|c|c|c|c|}
\hline \multirow{2}{*}{$\begin{array}{l}\text { Frequency category } \\
\text { (frequency range) }\end{array}$} & \multicolumn{4}{|c|}{ Acceptance criteria } \\
\hline & Operability for restart & Structural response & Combustible gas control & Operator radiation exposures \\
\hline $\begin{array}{l}\text { Anticipated } \\
\text { (frequency }>10^{-2} / \text { year) }\end{array}$ & $\begin{array}{l}\text { Correction of initiating } \\
\text { event allows initiation } \\
\text { of restart. }\end{array}$ & $\begin{array}{l}\text { Service Level A } \\
\text { (frequency }>1 / \text { year) } \\
\text { Service level B } \\
\text { (frequency }<1 \text { /year) }\end{array}$ & No combustion & $\begin{array}{l}\text { ALARA (frequency }>10^{-1} / \text { year) } \\
2 \mathrm{rem} \text { (frequency }<10^{-1} / \text { year) }\end{array}$ \\
\hline $\begin{array}{l}\text { Unlikely } \\
\left(10^{-4}<\text { frequency }<\right. \\
\left.10^{-2} / \text { year }\right)\end{array}$ & None specified. & Service level C & $\begin{array}{l}\mathrm{H}_{2}-\mathrm{O}_{2} \text { reaction (if any) } \\
\text { within the cabability of } \\
\text { installed treatment } \\
\text { systems. }\end{array}$ & $\begin{array}{l}5 \mathrm{rem} \text { (frequency }>10^{-3} / \text { year) } \\
10 \mathrm{rem} \text { (frequency }<10^{-3} / \text { year) }\end{array}$ \\
\hline $\begin{array}{l}\text { Extremely unlikely } \\
\left(10^{-6}<\text { frequency }<\right. \\
\left.10^{-4} / \text { year }\right)\end{array}$ & None specified. & Service level D & $\begin{array}{l}\text { No detonation. Spread of } \\
\text { fire to other parts of the } \\
\text { reactor prevented by } \\
\text { installed mitigation } \\
\text { systems (e.g., sprinkler } \\
\text { system). }\end{array}$ & $\begin{array}{l}25 \mathrm{rem} \text { (frequency }>10^{-5} / \text { year) } \\
250 \mathrm{rem} \text { (frequency }<10^{-5} / \text { year) }\end{array}$ \\
\hline
\end{tabular}





\section{REFERENCES}

1. ANS Plant Design Requirements, ORNL/TM-11625, Rev. 4, Martin Marietta Energy Systems, Inc., Oak Ridge National Laboratory, May 1992.

2. G. J. Russell and C. D. West, "International Workshop on Cold Neutron Sources," Los Alamos National Laboratory, Los Alamos, New Mexico, LA-12146-C (Conference), UC-413, (March 5-8, 1990).

3. "Advanced Neutron Source Reactor Cold Source Availability Study," ANS Project Transmittal 94-002, WBS 1.2.2, originated by C. T. Ramsey, Jan. 10, 1994.

4. L. C. Cadwallader, Cryogenic System Operating Experience Review for Fusion Applications, EGGFSP-10048, Idaho National Engineering Laboratory, Idaho Falls, Idaho, January 1992.

5. L. C. Cadwallader, Vacuum System Operating Experience Review for Fusion Applications, EGG-FSP11037, Idaho National Engineering Laboratory, Idaho Falls, Idaho, March 1994.

6. T. D. Marshall and L. C. Cadwallader, In-Vessel ITER Tubing Failure Rates for Selected Materials and Coolants, EGG-FSP-10928, Idaho National Engineering Laboratory, Idaho Falls, Idaho, March 1994.

7. Conceptual Safety Analysis Report, Advanced Neutron Source, ORNL/ANS/INT-33 V1, Martin Marietta Energy Systems, Inc., Oak Ridge National Laboratory, June 1992.

8. C. T. Ramsey et al., ANS Probabilistic Risk Assessment, ORNL/ANS/INT-50, Martin Marietta Energy Systems, Inc., Oak Ridge National Laboratory, February 1995.

10. Secretariat, American Nuclear Society, American National Standard Nuclear Safety Criteria for the Design of Stationary Pressurized Water Reactor Plants, ANSU/ANS-51.1-1983, American Nuclear Society, La Grange Park, Illinois, April 29, 1983.

11. USNRC Office of Standards Development, Standard Format and Content of Safety Analysis Reports for Nuclear Power Plants - LWR Edition, Regulatory Guide 1.70, Rev. 3, November 1978. 



\section{INTERNAL DISTRIBUTION}

1. S. J. Chang

2. D. H. Cook

3. J. M. Corum

4. W. G. Craddick

5. M. B. Farrar

6. G. F. Flanagan

7. R. G. Gilliland

8. R. C. Gwaltney

9-13. R. M. Harrington

14. W. R. Hendrich

15. R. L. Johnson

16. A. T. Lucas

17-19. C. R. Luttrell
20. T. J. McManamy

21. H. A. Mook

22. R. M. Moon

23-27. C. T. Ramsey

28. D. L. Selby

29. W. F. Swinson

30. C. D. West

31. G. T. Yahr

32-33. Central Research Library

Document Reference Section

34. ORNL Patent Section

35-36. Laboratory Records Department

37. Laboratory Records Department, RC

38. Y-12 Technical Library

\section{EXTERNAL DISTRIBUTION}

39. U.S. Department of Energy, Oak Ridge Operations, FEDC, MS-8218, P.O. Box 2009, Oak Ridge, TN 37831-8218

40-41. Office of Scientific and Technical Information, P.O. Box 62, Oak Ridge, TN 37831 
